\title{
Distant homologies and domain conservation of the Hereditary Spastic Paraplegia protein SPG11/ALS5/spatacsin
}

\author{
Alexander L Patto and Cahir J O'Kane*
}

Department of Genetics, University of Cambridge, Downing Street, Cambridge, CB2 3EH

${ }^{*}$ Corresponding author Email: c.okane@gen.cam.ac.uk

\begin{abstract}
Loss-of-function mutations in SPG11 protein (spatacsin) are a common cause of autosomal recessive hereditary spastic paraplegia with thin corpus callosum. To identify regions of the protein that may have functions that are disrupted in disease, we carried out bioinformatic analyses of its conserved regions. An N-terminal region of around 650 amino-acid residues, present in SPG11 across a wide range of metazoan animals, was missing from many insect lineages. Evolutionary loss of this domain correlated with loss of its binding partner, the AP-5 adaptor complex, suggesting that its main function is interaction with AP-5 in intracellular trafficking, and that the remainder of SPG11 carries out AP-5-independent functions. At the Cterminus of SPG11, a spatacsin_C domain showed sequence similarity and predicted structural homology to the Vps16_C domain of the HOPS complex protein Vps16. It localized to acidic compartments, consistent with a role in endolysosomal or autolysosomal transport, like Vps16. Mass spectrometry analysis of binding partners of this domain identified membrane trafficking proteins, some SM proteins, and several aminoacyl-tRNA synthetases. Since mutations affecting SPG11 or aminoacyl-tRNA synthetases can both cause Charcot-MarieTooth neuropathy (CMT) type 2, we suggest autolysosomal trafficking as a target process in CMT type 2.
\end{abstract}




\section{Introduction}

Loss-of-function mutations in SPG11 commonly result in autosomal recessive Hereditary Spastic Paraplegia (ARHSP) with thinning of the corpus callosum (TCC) (Stevanin et al. 2007). SPG11 is the most common recessive HSP, with HSP-causing mutations identified throughout the coding region. SPG11 mutations can also cause other degenerative disorders including juvenile ALS (Orlacchio et al. 2010; Daoud et al. 2012), juvenile Parkinson's disease and dopaminergic neuron loss (Guidubaldi et al. 2011; Anheim et al. 2009), Kjellin's syndrome, or the peripheral neuropathy Charcot-Marie-Tooth disease (Fridman and Murphy 2014; Montecchiani et al. 2016).

Loss of SPG11 in mammals leads to axonal pathology, including axon outgrowth defects in mice (Pérez-Brangulí et al. 2014). Young Spg11 knockout mice have severe neuronal loss in the cerebellum, motor cortex and Purkinje cells (Varga et al. 2015). Externally, mice develop a progressive gait disorder, developing ataxia after 12 months (Varga et al. 2015), similar to symptoms of SPG11 patients (Zhao et al. 2013). In zebrafish, severe knockdown of Spg11 or Spg15 led to similar defects in spinal motor neuron axon outgrowth and locomotion difficulties (Martin et al. 2012). Spg11 phenotypes in animal models and humans are broadly consistent, suggesting important roles for SPG11 in neuronal development and function.

SPG11 localizes to Lamp1-positive compartments in human fibroblasts (Hirst et al. 2013), which comprise lysosomes (Rohrer et al. 1996), autolysosomes (Yu et al. 2010) and late endosomes (Szymanski et al. 2011). SPG11 and its binding partner SPG15 show structural homology with clathrin heavy chain and COP1 subunits (Hirst et al. 2011; Hirst et al. 2013), and interact with the adaptor protein complex AP-5 (Renvoisé et al. 2014; Słabicki et al. 2010; Hirst et al. 2011), by binding of the SPG11 N-terminus to AP-5 (Hirst et al. 2013). While this is superficially similar to the recruitment of clathrin to budding vesicles by adaptors, knockdown of $A P 5 z 1$ has in fact no effect on localization of SPG11 or SPG15, and knockdown of either SPG11 or SPG15 disrupts AP-5 localization (Hirst et al. 2013). Loss of SPG11, SPG15 or the AP-5 subunit AP5z1 causes accumulation of the mannose 6-phosphate receptor (CIMPR) in early endosomes (Hirst et al. 2013), and proteomic analyses of of AP5z1 knockout cells suggest a defect in transport from late endosomes to the Golgi (Hirst et al. 2018). Therefore, SPG11, SPG15 and AP-5 appear to share trafficking roles that may be disrupted in HSP.

SPG11 must also have AP-5-independent roles, which may account for disease phenotypes like ALS, PD or CMT, not so far found in human AP-5 mutant genotypes. Mutations in AP5z1 are associated with HSP, although protein null alleles appear in general to have later onset (Hirst et al. 2016; Słabicki et al. 2010) than SPG11 or SPG15 (Pensato et al. 2014; Boukhris 
et al. 2008; Stevanin et al. 2007). Further, Drosophila contains both SPG11 and SPG15 homologs, but lacks AP-5 (Hirst et al. 2011). Such an AP-5-independent role appears to be in autophagic lysosome reformation (ALR) (Chang et al. 2014; Varga et al. 2015), which replenishes free lysosomes after periods of increased autophagy (Yu et al. 2010). Loss of SPG11 or SPG15 results in enlarged or excess autolysosomes, and loss of Lamp1-positive tubules on autolysosomes, thought to be an intermediate in ALR (Chang et al. 2014; Vantaggiato et al. 2013; Varga et al. 2015). Levels of LC3-II, an indicator of autophagy flux (Mauvezin et al. 2014), increase, but not Lamp1, suggesting aberrant lysosome-dependent clearance of autophagosomes (Chang et al. 2014; Varga et al. 2015). Spg11 knock-out mice display fewer free lysosomes in Purkinje cell somata (Varga et al. 2015), consistent with impaired ALR in vivo. Mutant SPG15 patient fibroblasts accumulate autophagy substrate p62 (Vantaggiato et al. 2013), and SPG11 knock-out Purkinje cells show increased p62 in Lamp1positive compartments, suggesting that autolysosomes are not completely functional (Varga et al. 2015). The above findings suggest a key role for SPG11 in ALR, and that ensuing accumulation of undegraded material in the absence of SPG11 may be a cause of neuronal degeneration (Varga et al. 2015).

However, the molecular role of SPG11 in autophagic trafficking, the steps it affects, and the nature of its AP-5- independent function are not clear. To identify potential roles for SPG11 in this process, we undertook bioinformatic analyses of the protein. We found that the presence or absence of the $\mathrm{N}$-terminal region, found in most metazoan lineages, correlates with the presence or absence of the AP-5 adaptor complex, suggesting that the main function of the Nterminal region is to interact with AP-5. We also found evidence that the spatacsin_C domain at the C-terminus of SPG11 is homologous to the Vps16_C domain, and identified binding partners that might provide some common mechanisms for CMT pathology between SPG11 and aminoacyl-tRNA synthetases. 


\section{Materials and Methods}

Amino acid alignments and protein function prediction. Multiple alignments of Spg11 sequences only were performed using Kalign multiple alignment, with gap open penalty of 13 (http://www.ebi.ac.uk/Tools/msa/kalign/) (Lassmann and Sonnhammer 2005), or MUSCLE multiple alignment (http://www.ebi.ac.uk/Tools/msa/muscle/) (Edgar 2004). Distant homologs were identified and aligned using HHpred (Zimmermann et al. 2018) on the MPI bioinformatic server (https://toolkit.tuebingen.mpg.de/hhpred). Tertiary structure prediction by homology was performed by submitting a multiple sequence alignment generated on the HHpred site to Modeller (Webb and Sali 2016). Interaction maps and GO and KEGG term enrichment were performed by submitting the list of Drosophila genes to String (http://string-db.org)

Immunoprecipitation and mass spectrometry of GFP- tagged Spg11 C-terminus. We used Gateway recombination cloning technology (Invitrogen, UK) to generate a GFP::Spg11C-term (nucleotides 3051-4094 of Drosophila Spg11 gene). The entry and destination vectors were pDONR211 (Thermo Fisher, 12536017), Act5-Nterm GFP tag (driven by Actin5 promoter, pAGW plasmid, https://emb.carnegiescience.edu/drosophila-gateway-vector-collection) and PMT-pcBlast-Nterm GFP tag (CuSO4 Inducible promoter, Thermo Fisher V413020).

The C-terminal region of Spg11 (amino acid residues 1468-1815) was amplified using Phusion Flash High-Fidelity polymerase (Thermo Fisher F548L) and extracted from electrophoresis gel using QIAquick Gel Extraction Kit (Qiagen 28704) according to manufacturer's protocol. The C-terminus from codons 1468-1815 was amplified using primers Spg11_C_f1 (GGGGACAAGTTTGTACAAAAAAGCAGGCTTC CAC CTG TGT TTC GTG CAC GA; forward sequence annealing to codons 1468-1473, HLCFVH shown as triplets) and Spg11_C_r1 (GGGGACCACTTTGTACAAGAAAGCTGGGTC CTA CGT ATC TCC TGC TGT GTG GA; complementary sequence annealing to codons 1810-1815 HTAGDT and stop, shown as triplets); they also contained additional homology to pDONR 211 allowing homologous recombination and integration of Spg11 C-terminus. BP and LR reactions conducted according to the Gateway ${ }^{\circledR}$ recombination cloning technology manual, and transformed into DH5-alpha cells according to the manufacturers instructions (Subcloning efficiency, ThermoFisher 18265017). Clones were sequenced (GATC-Biotech) using M13f and M13r primers, to ensure sequences were correct.

Transfection of Drosophila Mel-2 Cells. Drosophila Mel-2 cells (Schneider 1972) were grown at $25^{\circ} \mathrm{C}$ in standard sterile cell flasks in Express SFM medium (LifeTechnologies), containing penicillin streptomycin (ThermoFisher) and L-glutamine (ThermoFisher). All cell 
work was carried out in a sterile hood. Prior to transfection, cells were grown to high confluence and seeded in $2 \mathrm{ml}$ Express SFM (LifeTechnologies) in a 6-well plate, then left for 2 hours. To transform Mel-2 cells with GFP-tagged Spg11 C-terminus, $3 \mu \mathrm{g}$ of plasmid DNA was diluted in $100 \mu \mathrm{lddH_{2 }}$ O in a microfuge tube. A helper plasmid $(0.5 \mu \mathrm{g})$ was added in parallel with Act5Nterm GFP tag to confer Mel-2 cells with blasticidin resistance. Next, $15 \mu$ of FuGene-HD transfection reagent (Promega E2311) was applied directly to the center of the microfuge tube, and mixed thoroughly by gently pipetting up and down, before incubation for 15 minutes to allow formation of transfection complexes. Transfection mixture was added to the cells slowly, and the cell culture was subsequently incubated at $25^{\circ} \mathrm{C}$ for 12 hours.

Expression of GFP-tagged Spg11 C-terminus was confirmed by confocal microscopy. Mel-2 cells were seeded on sterile glass cover slips for 20 minutes, before fixing in ice cold methanol for 10 minutes. When necessary, cells were exposed to Lysotracker $®$ for 10 minutes prior to fixation. Cells were mounted on glass slides before imaging.

Transfected Mel-2 cells were selected using blasticidin (ThermoFisher, USA, A1113903) for 5 passages. Cells were passaged when confluence approached $80 \%$. They were then expanded to $7 \times 10^{8}$ in $300 \mathrm{ml}$ of Express SFM medium, in large sterile conical flasks, shaken at $80 \mathrm{rpm}$ at $25^{\circ} \mathrm{C}$. Transgene expression was induced 24 hours prior to protein extraction by adding 500 $\mu \mathrm{M} \mathrm{CuSO}$. The PMT-pcBlast-Nterm GFP tag, lacking Spg11, was used as a control.

Drosophila Mel-2 cell immunoprecipitation. Drosophila Mel-2 cells were transferred into 50 $\mathrm{ml}$ falcon tubes and pelleted at $5000 \mathrm{rpm}$, before resuspending cells in $8 \mathrm{ml}$ of RIPA buffer (Sigma R0278), containing protease inhibitors (Sigma). Cells were lysed on ice using electronic homogenizer, 5 times, each for 30 seconds, with 30 seconds cool down time in between. Lysed cells were centrifuged for 30 minutes at $10,000 \mathrm{rpm}$ at $4^{\circ} \mathrm{C}$, before supernatant was collected. For immunoprecipitation, ChromoTek GFP-Trap A (ChromoTek gta-10, Germany) was used according to manufacturer's instructions. GFP-tagged Spg11 C-terminusbound beads were sent to for mass spectrometry analysis at the Mass Spectrometry Laboratory, Institute of Biochemistry and Biophysics, PAS. Poland.

Data reporting. No institutional ethical review was required. The study was not pre-registered. Randomization, blinding, and sample size calculations were not applicable. No animals were used. The study was exploratory. Statistical calculations were all carried out by the bioinformatic software described. Clones can be provided on request, or generated from the information provided in the paper. 


\section{Results}

N-terminal AP-5-binding region of SPG11 is absent in insect lineages. We used bioinformatic tools to identify potential functional domains within SPG11. Multiple alignments show extensive conservation along the length of SPG11 proteins, but with no identifiable domains of known function (Hirst et al. 2011; Hirst et al. 2013). The best characterized molecular function is a predicted beta-propeller-like fold in the $\mathrm{N}$-terminal 500 amino-acid residues of human SPG11, which interacts with the AP-5 adaptor (Hirst et al. 2013). Multiple alignment (Lassmann and Sonnhammer 2005) identified this region in all deuterostomes aligned (Fig. 1), and in many protostomes, including arachnids, molluscs, annelids and brachiopods. However, Drosophila and other insects lack approximately 650 amino acids from the $\mathrm{N}$-terminus of SPG11 (known as CG13531 in Drosophila), which contains the AP-5-binding domain (Fig. 1).

AP-5 is an ancient adaptor complex, but has frequently been lost during eukaryote evolution. To test whether its loss correlates with loss of the SPG11 N-terminus, we tested a range of metazoans for the presence of any of the four AP-5 subunits (Hirst et al. 2011). AP-5 is present in basal animal phyla such as Cnidaria, the sponge Amphimedon, and the Placozoan Trichoplax; it is also found widely in deuterostomes (Figs S1-S4). In protostomes, it is found in molluscs (Octopus, Lottia, Crassostrea, Biomphalaria), the brachiopod Lingula, the annelid Capitella, the priapulid worm Priapulus, and some arthropods (Limulus, Parasteatoda), but not in insects. Most organisms that lack the SPG11 N-terminal region (Figure 1) also lack AP-5 (Figs S1-S4), suggesting that the primary role of the N-terminus of SPG11 is to bind AP-5.

In a few species, we found an SPG11 N-terminal domain, but not AP-5: the arthropods Sarcoptes and Metaseiulus, and the mollusc Aplysia (Figure 1). However, the arthropods most closely related to Sarcoptes and Metaseiulus (Limulus, Parasteatoda), and other molluscs (Octopus, Lottia), possess both AP-5 and the SPG11 N-terminus, suggesting either that AP-5 is present in Sarcoptes, Metaseiulus and Aplysia but not yet annotated, or these species have lost AP-5 relatively recently, but not yet the SPG11 N-terminus.

\section{SPG11 C-terminus has predicted homology with the Vps33-binding domain of Vps16.}

Human and Drosophila SPG11 share 16\% identity across the entire protein sequence, with higher identity (31\%) across a C-terminal region of around 300 amino acid residues (Fig. 2A). This region is designated as a Spatacsin_C domain (Pfam 14649; Interpro IPR028107), but its function or structure is unknown. To identify domains homologous to this region of SPG11, we used Drosophila and human SPG11 C-terminal domain sequences as queries in a HHpred search; this search can identify distant homologies between proteins using the Structural 
Classification of Proteins database (SCOP) (Söding et al. 2005), and previously predicted a beta-propeller-like region in the N-terminal AP-5-binding domain (Hirst et al. 2013). It also predicts homology of some regions of Drosophila SPG11 to coatomer subunits (Figure 2B), as previously predicted for human SPG11. At the C-terminus, HHpred predicted homology across most of the C-terminal 300 amino acid residues, to PDB crystal structure 4KMO (DOI 10.2210/pdb4kmo/pdb), comprising the Vps33-Vps16 HOPS subcomplex (Figure 2B,C), which contains the C-terminal region of Vps16 (Vps16_C, Pfam ID: PF04840) and the SM protein Vps33 (Baker et al. 2013; Graham et al. 2013).

Fig. 1

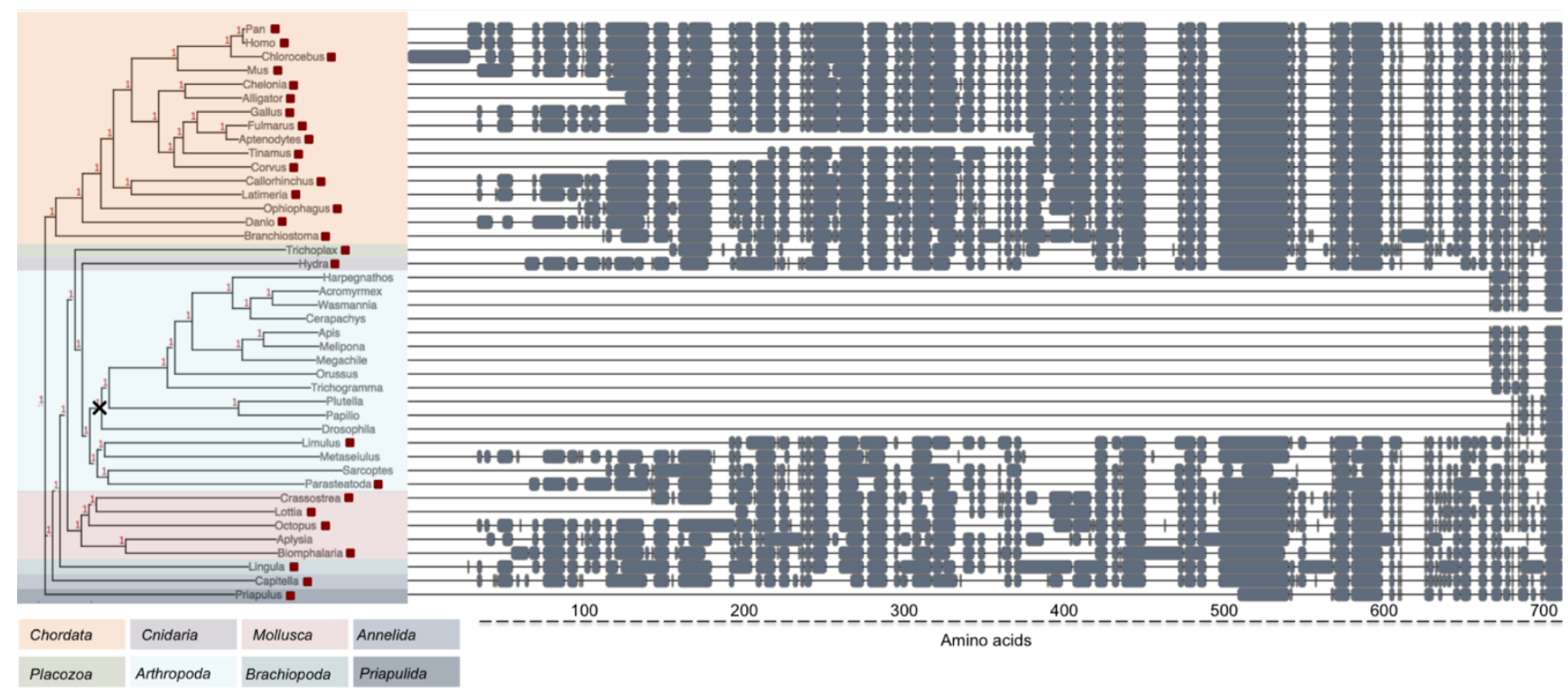

Fig. 1. SPG11 phylogenetic tree across a range of metazoans. Left: Phylogenetic tree of SPG11 amino acid sequence, made using Kalign multiple alignment (Lassmann and Sonnhammer 2005). Organisms containing AP-5 (Figs S1-S4) are shown by red squares. Shaded regions denote different phyla. Right: A condensed overview of aligned SPG11 Nterminal regions, created using online tree viewer (http://etetoolkit.org/treeview/). Predicted loss of $\mathrm{N}$-terminal region occurs prior to the divergence of insects (cross). 


\section{Fig. 2}
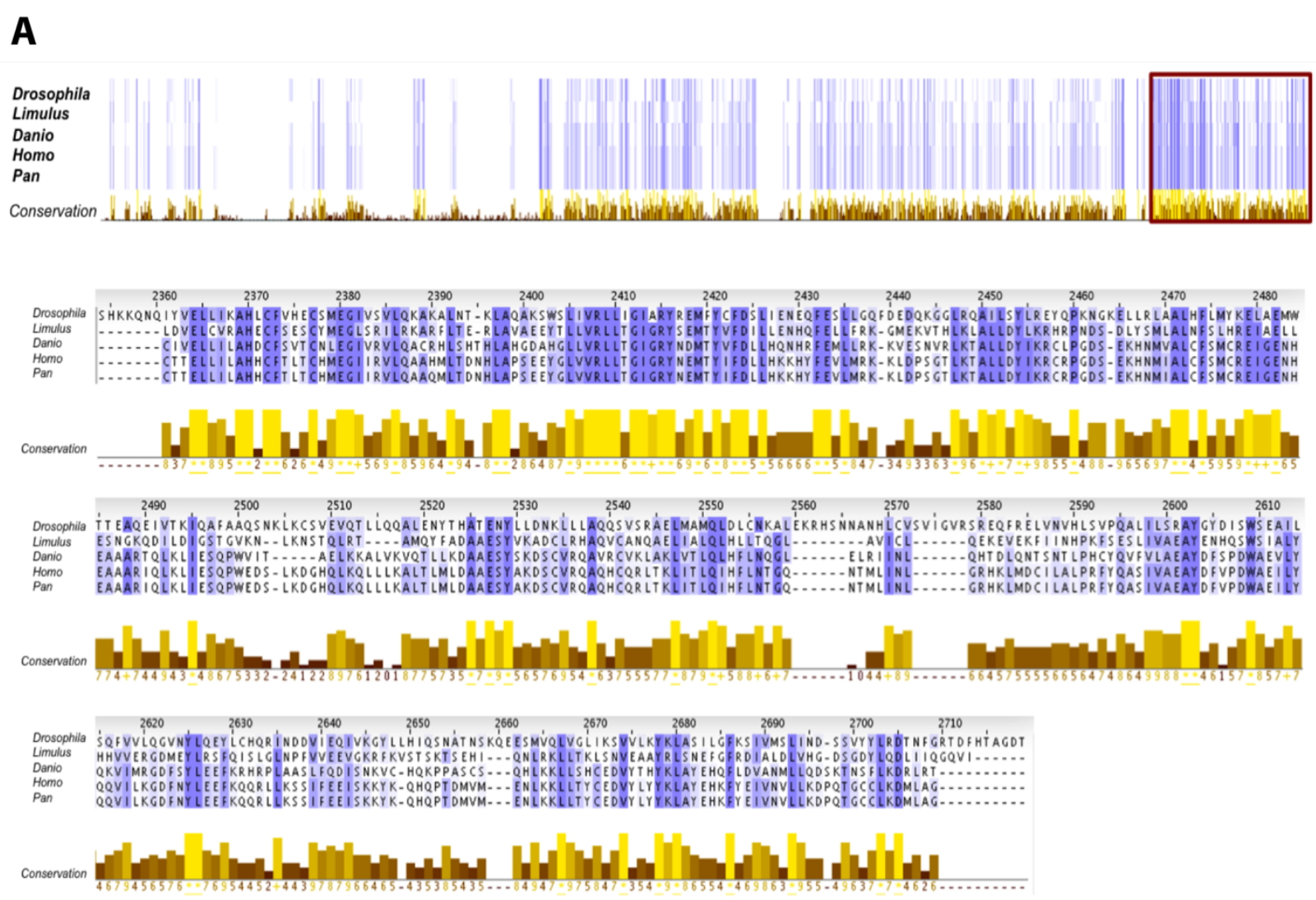

B

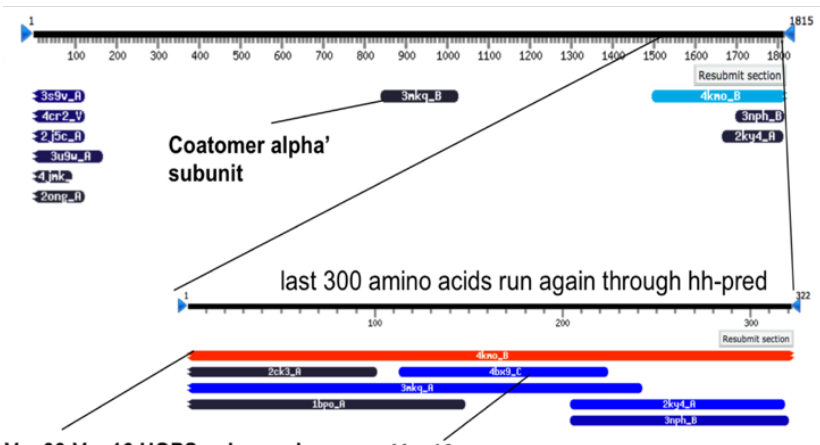

Vps33-Vps16 HOPS subcomplex Vps16

\section{C}

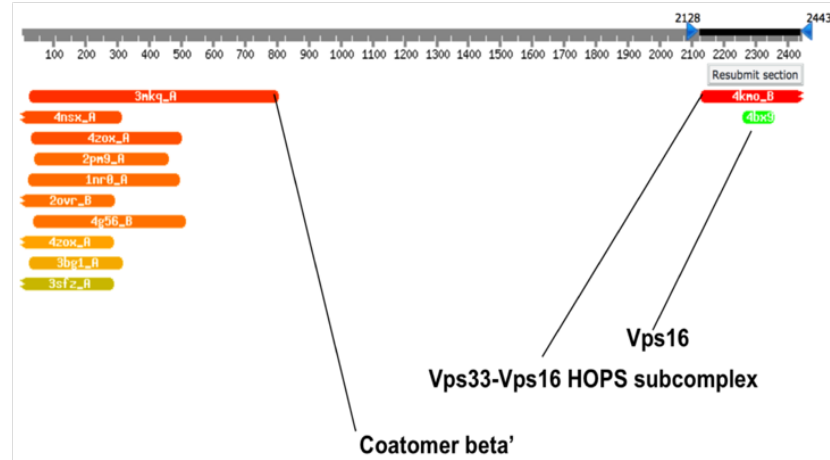

Fig. 2. Sequence conservation across the length of Spg11. A. MUSCLE multiple alignment of SPG11 from D. melanogaster, L. polyphemus, D. rerio, H. sapiens and $P$. troglodytes, shown in Jalview. Top panel: blue shaded regions show regions of amino acid identity between organisms; intensity of blue corresponds with level of identity. Yellow bars at the bottom denote conservation level between organisms for individual amino acid positions. Red box indicates SPG11 C-terminal region with high conservation. This region is expanded in the lower panels to show conservation and alignment of amino acid sequences. B: HHpred of Drosophila SPG11 predicts coatomer homology in the central region of the proteins, and homology to Vps33-Vps16 HOPS subcomplex and Vps16 in the C-terminal region. C: HHpred analysis of human SPG11 predicts extended homology to coatomer beta' subunit at the N-terminus and to Vps33-Vps16 HOPS subcomplex and Vps16 at the C-terminus. 
To verify the sequence conservation of the SPG11 C-terminus to the Vps33-Vps16 subcomplex, we used six phylogenetically diverse SPG11 C-terminal domains as a single query in a HHpred alignment. After other Spg11 C-termini, the next most closely related sequences were the C-terminal domains of the Vps16a and Vps16b families (Supplementary Fig. 5). A multiple sequence alignment in HHpred using a small number of Spg11, Vps16A and Vps16B proteins, found extensive similarity between all three families of proteins, with identical or conserved amino acid residues at many positions (Figure 3A). However, many known Vps33-binding residues of the Vps16_C domain of Vps16 (Baker et al. 2013; Graham et al. 2013) were either missing or not conserved in SPG11 (Figure 3A). Together these results support homology of the SPG11 C-terminal domain to Vps16_C, but do not strongly support binding to Vps33.

SPG11 C-terminus predicted tertiary structure similar to Vps16_C. The Vps16_C domain forms an alpha-solenoid with 17 alpha-helices; it binds to all 3 domains of Vps33, arching around Vps33, its $\mathrm{N}$-terminal region lying in a groove between Vps33 domains 1 and 2 (Baker et al. 2013; Graham et al. 2013). We assessed whether the SPG11 C-terminus might adopt a similar structure to Vps16_C, using Modeller tertiary structure prediction (Webb and Sali 2016). To give more weight to conserved residues for modeling, we tested the multiple alignment of six Spg11 sequences (Supplementary Fig. S5) for predicted similarity to the tertiary structure of Vps16_C (4KMO:B, https://www.rcsb.org/). This analysis predicted an extensive alphahelical structure for the Spg11 C-terminus, with the majority of helices at positions compatible with those in Vps16_C (Fig. 3B). The potential of the Spg11 C-terminus to adopt a tertiary structure like Vps16_C further supports a model of its origin as a distant homolog of Vps16_C.

\section{Fig. 3. SPG11 C-terminus shows conservation with Vps16_C domains.}

A. Multiple alignment of Spg11 C-terminus with sequences from two Vps16A and two Vps16B subfamily members, grouped by color. We generated a multiple sequence alignment in HHpred (Zimmermann et al. 2018), exported to JALview, and made minor adjustments manually. Asterisks below alignment show residues that mostly conserved, or show only conservative changes, between the Spg11 sequences and at least one of the Vps16 sequences. Gray boxes below alignment denote Vps33-binding residues in Vps16a (Baker et al. 2013; Graham et al. 2013).

B. Tertiary structure prediction of SPG11_C was performed by forwarding a HHpred multiple sequence alignment of six Spg11_C domains from the HHpred site to Modeller (Webb and Sali 2016), to align with the tertiary structure of Vps16_C (4KMO:B, https://www.rcsb.org/). Stereo pairs show actual structure of Vps16_C and predicted structure of Spg11_C, either alone (left pairs, overlaid in top row, singly in lower rows), or bound to Vps33a (right pairs). 


\section{Figure 3}

A
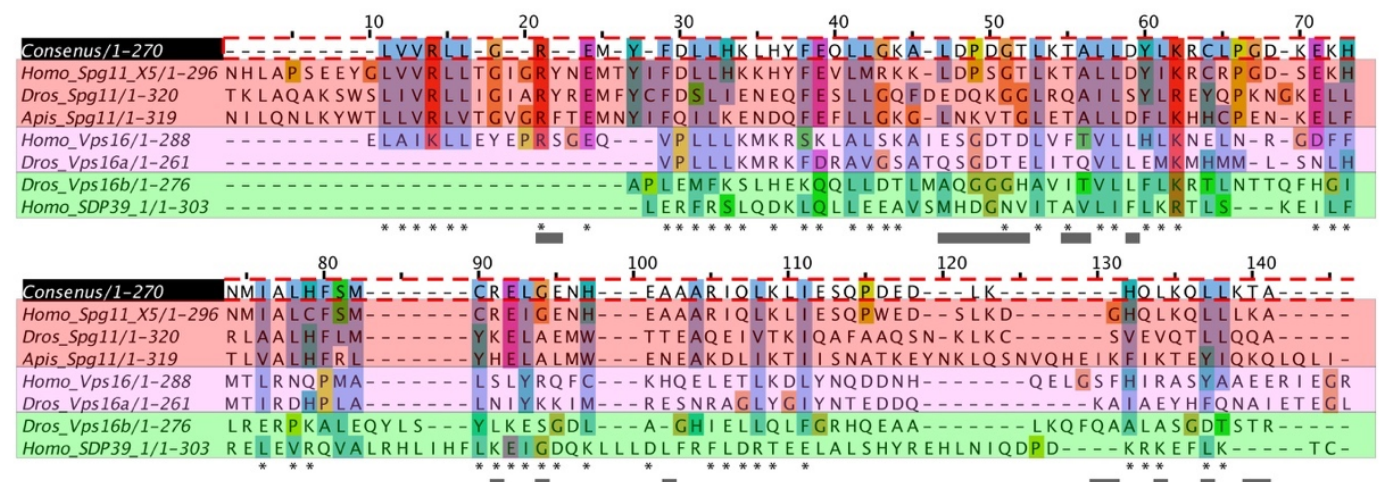

Homo_SDP3911/1-303 RELEVRQVALRHLIHFLKEIGDQKLLLDLFRFLDRTEELALSHYREHLNIQDPD- ${ }_{* * *^{*}}^{* *^{*}}$

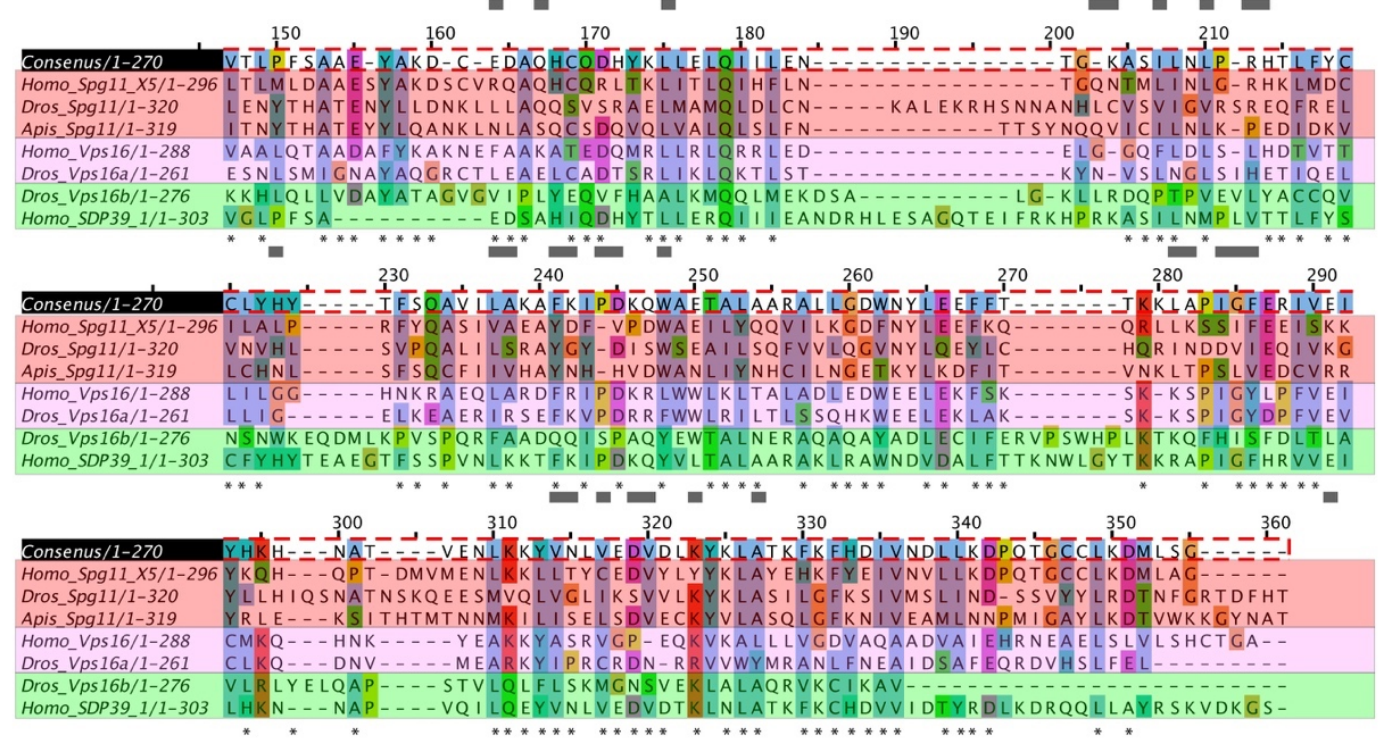

B

Vps16_C and Spg11_C

With Vps33a

Overlay
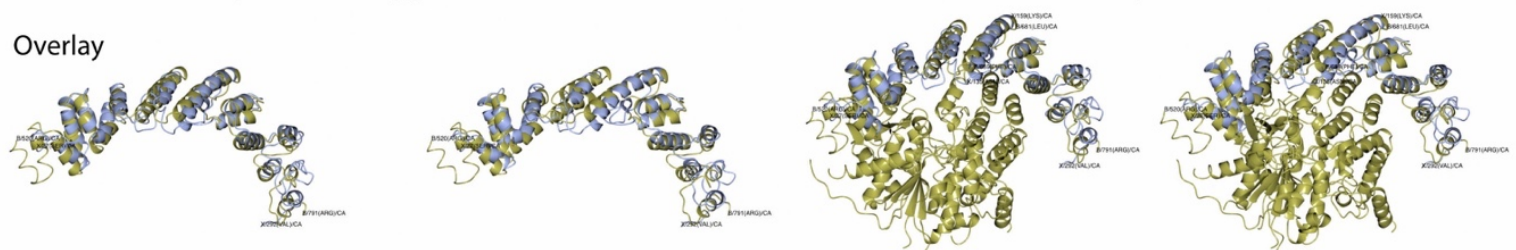

Spg11_C

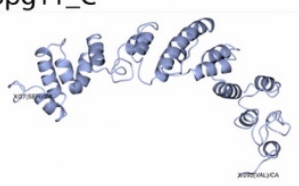

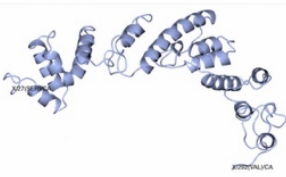
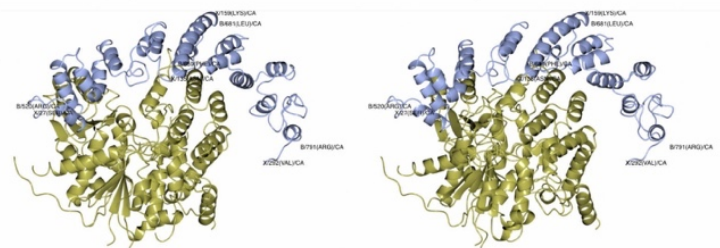

Vps16_C
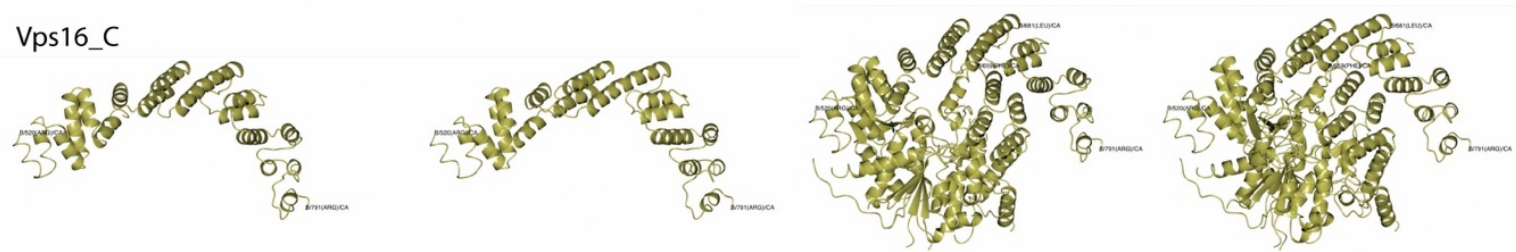
GFP-tagged SGP11 C-terminus overlaps with acidic compartments. To investigate whether the SPG11 C-terminus localized to endo/auto/lysosomal compartments like Vps16 (Kim et al. 2001; Schröder et al. 2007; Wartosch et al. 2015) and Spg11 (Hirst et al. 2012; Murmu et al. 2011; Varga et al. 2015), we expressed GFP::Spg11-C (amino acid residues 1468-1815) in Drosophila Mel-2 cells. GFP::Spg11-C localized widely through the cytosol, but was often concentrated in puncta that overlapped with acidic LysoTrackerß-positive compartments in many cells (Figure 4), showing that much of it localized to endo/auto/lysosomal compartments.

Fig. 4
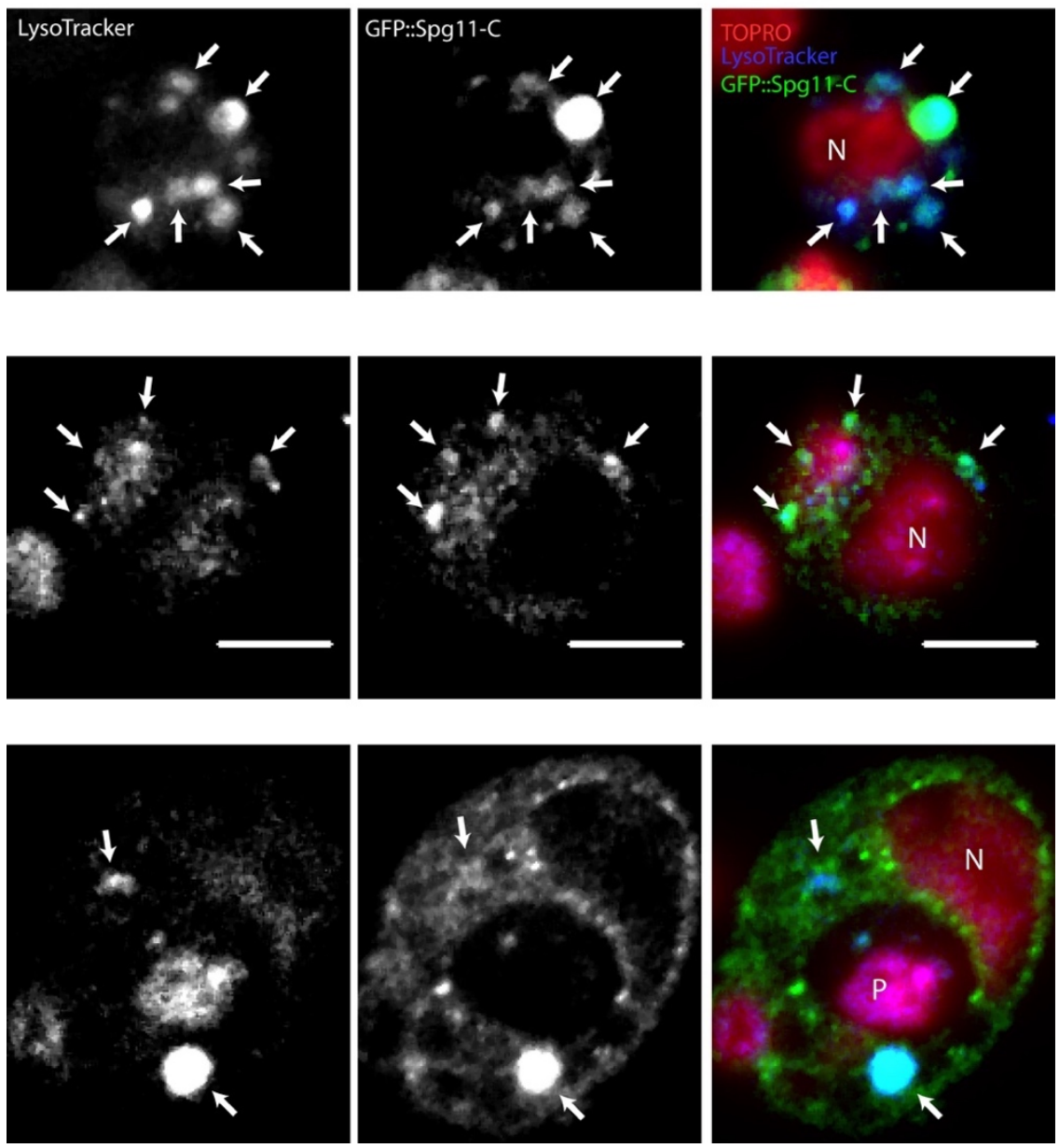

Fig. 4. Localisation of GFP::Spg11-C in Drosophila Dmel-2 cells. Single sections of three different transfected cells, showing overlap of many GFP::Spg11-C puncta with LysoTracker® -positive acidic compartments (examples shown by arrows). Nuclei $(\mathrm{N})$ are stained lightly with TOPRO-3. One likely phaogosome $(\mathrm{P})$ is visible. Scale bar $=5 \mu \mathrm{m}$. 
Identification of SPG11 C-terminus binding partners by mass spectrometry. To test further the functionality of the SPG11 C-terminus, we conducted mass spectrometry analysis on Drosophila GFP::Spg11-C expressed in Mel-2 cells. We established two cell lines: one with GFP::Spg11-C driven by a constitutively active promoter (Act5-GFP::Spg11-C) and one by a $\mathrm{CuSO}_{4}$-inducible promoter (PMT-GFP::Spg11-C). A Mel-2 cell line expressing GFP (inducible by $\mathrm{CuSO}_{4}$ ) was used as a negative control.

Mass spectrometry analysis of purified GFP::Spg11-C from $\mathrm{CuSO}_{4}$-induced cells identified 898 proteins not found in the GFP negative control, whereas analysis of constitutively expressed GFP::Spg11-C identified 231 proteins (Fig. 5A); the top 100 hits from each analysis are listed in Tables 1 and 2. The $\mathrm{CuSO}_{4}$-induced cells generated more protein hits that showed higher scores than in the control cell line, compared to the constitutive cells (Figure 5B), suggesting that GFP::Spg11-C was more highly expressed in $\mathrm{CuSO}_{4}$-inducible than in constitutive cells. 128 proteins were detected in both lines (Fig. 5A; Table 3), providing increased confidence in the specificity of these interactors, although this overlapping list may be missing some genuine interactors identified in the $\mathrm{CuSO}_{4}$-induced cells.

GFP::Spg11-C was detected in both cell lines, but not in the GFP negative control line, confirming its expression, and the mass spectrometry protocol (Figure 5B); it was the highest scoring hit in the $\mathrm{CuSO}_{4}$-induced line, but not in the constitutively expressing cell line (Figure 5B). Reassuringly, the SPG11 binding partner, SPG15, was identified in the inducible cell line, although not in the constitutive one. To assess the potential biological roles of Spg11, we tested for enrichment of molecular function, biological process, and pathway terms among the interactors identified in both cell lines. Membrane traffic and organization terms were among those most enriched (Table 4; Fig. 6). We also noticed several actin-binding proteins, and motor proteins of the kinesin, dynein and myosin families (Tables 1-3, entries in bold; Fig. 6).

One unexpected class of SPG11-C binding partners were aminoacyl-tRNA synthetases, which charge specific tRNAs with the correct amino acid for translation. These were the highest ranking class of interactors with a specific enzymatic activity as a molecular function, and the highest ranking KEGG pathway (Table 4). Five of these were pulled down (Figure 6; Table 5). These included Drosophila homologs of methionyl-tRNA synthetase (MARS) and alanyl-tRNA synthetase (AARS), mutations in which are causative for Charcot-Marie-Tooth (CMT) Type 2 neuropathy (McLaughlin et al. 2012; Gonzalez et al. 2013; Timmerman et al. 2014; Wei et al. 2019), as well as serine- valine- and glutamine- tRNA synthetases (Table 5). The MARS ortholog was identified with a particularly high score in the inducible line (Table 1). 


\section{Fig. 5}

A

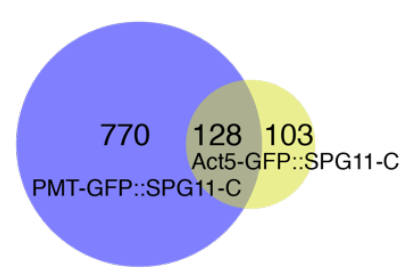

B

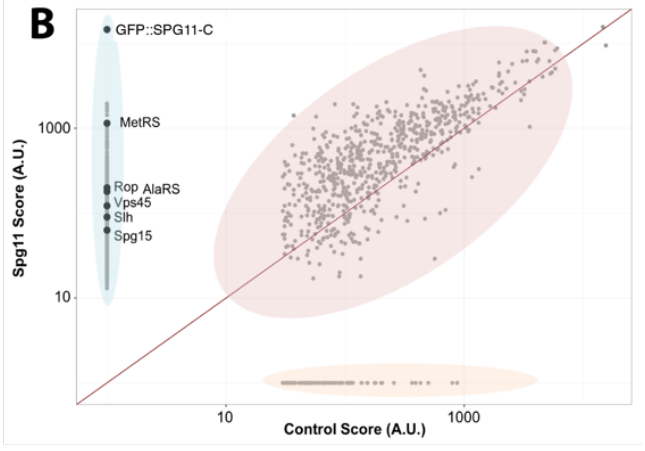

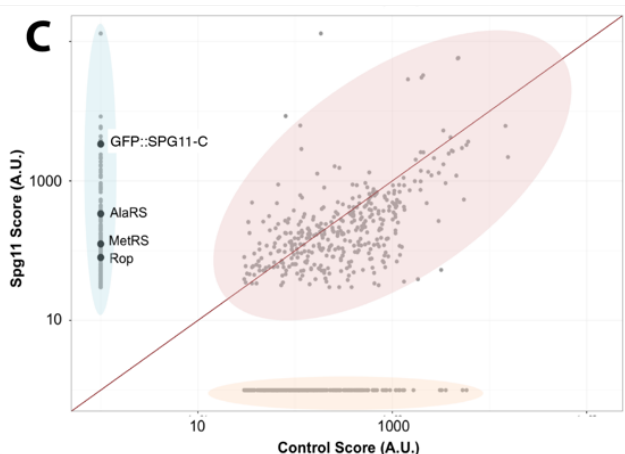

Fig. 5. Binding partners of Spg11_C identified by mass spectrometry. A. Venn diagram of Spg11_C interactors identified by mass spectrometry of PMT- GFP::Spg11-C and Act5GFP::Spg11-C cell lines. B,C. Mass spectrometry output for purified GFP::Spg11-C from the Drosophila Mel-2 cell line expressing PMT-GFP::Spg11-C (B) or Act5-GFP::Spg11-C (C), compared to control cells lacking GFP::Spg11-C. Graphs plot the percentage difference between test and control. $\mathbf{B}$ has more proteins with a higher score than the equivalent protein in the negative GFP control, indicated by the majority of the protein hits residing above the equivalence line (in red). However, graph $\mathrm{C}$ has fewer proteins above the equivalence line. Scores of GFP::Spg11-C, Rop, Vps45, Slh, MetRS (MARS), AlaRS (AARS) and Spg15 are highlighted. 
Fig. 6
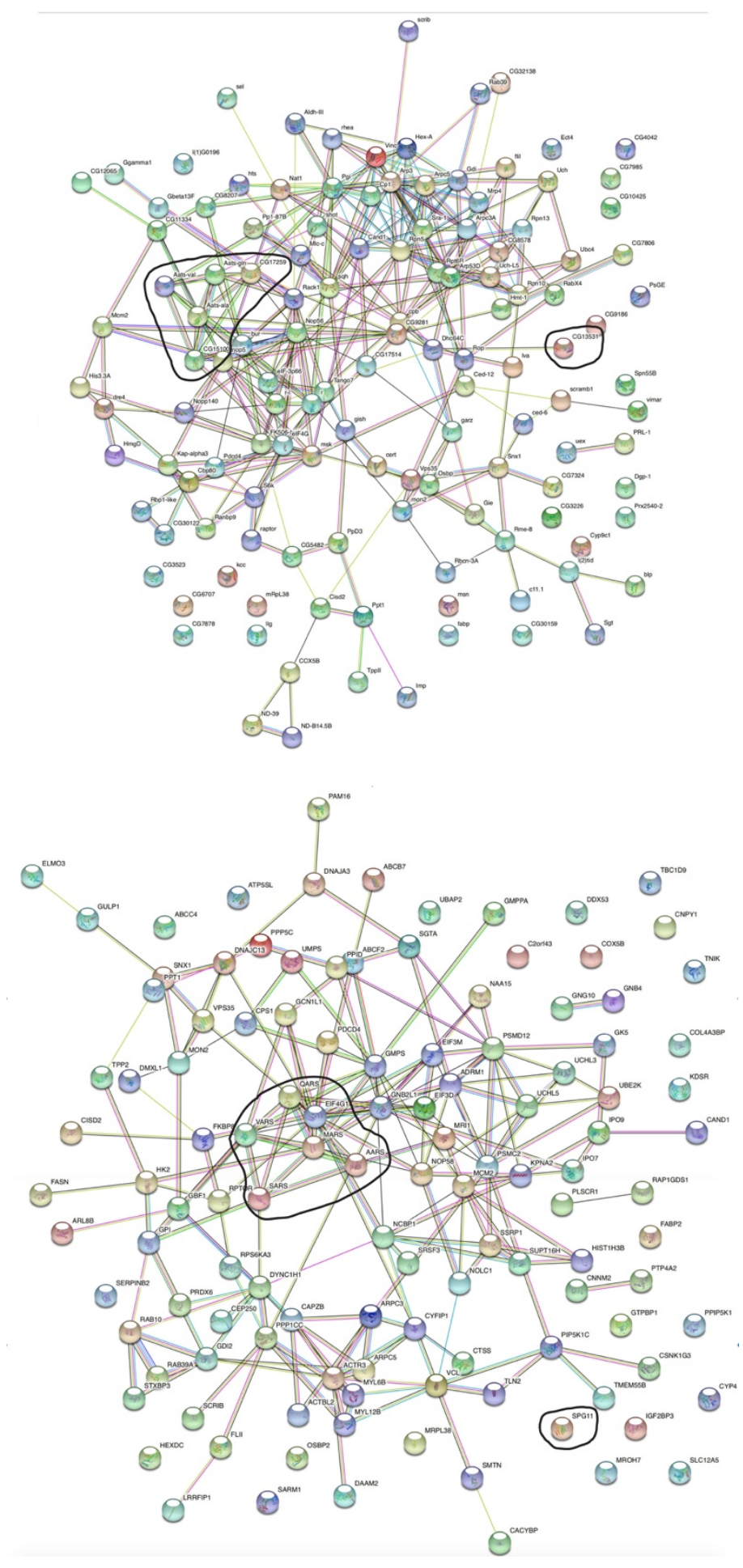

Fig. 6. Interactions among Spg11_C binding partners found in both cell lines. Top: Drosophila Spg11_C partners. Bottom: human orthologs of Drosophila Spg11_C partners. Maps were generated using String (http://string-db.org). Aminoacyl-tRNA synthetases (including CG17259/SerRS and CG15100/MetRS) are grouped inside a freehand line; human EIF4G1 is an unrelated "bystander". Drosophila and human CG13531/SPG11 are highlighted. 
Since the Vps16_C domain of Vps16 recruits the SM proteins Vps33a to the HOPS complex (Wartosch et al. 2015), we expected to find one or more SM proteins as binding partners of the spatacsin_C domain. Drosophila has 5 known SM proteins (Table 6). Three of these, Rop, Vps45 and Slh were identified in the output of the $\mathrm{CuSO}_{4}$-induced line (Figure 5B; Table 7). Rop was identified in both cell lines (Figure 5B; Table 3); we did not identify Vps33a (Carnation) or Vps33b as binding partners in either line.

\section{Discussion}

Bioinformatic analyses predict functional roles of the $\mathrm{N}$ - and $\mathrm{C}$-termini of SPG11. Our bioinformatic analyses make interesting predictions about two regions of the SPG11 protein family. First, our phylogenetic analyses show that the evolutionary presence of a conserved $\mathrm{N}$-terminal region correlates strongly with the presence of the AP-5 adaptor complex, suggesting that binding to AP-5 is the only essential function of this $\mathrm{N}$-terminal region. Second, the SPG11 C-terminus shows higher conservation than most other parts of SPG11, and both human and fly variants show predicted structural homology with the Vps16 C-terminus (Vps16_C, Pfam ID: PF04840) (Figure 2C). The model of homology is supported by many conserved residues in a multiple sequence alignment of spatacsin_C and Vps16_C domains (Figure $3 \mathrm{~A}$ ) and tertiary structure prediction by homology (Figure 3B).

The Vps16_C domain (Pfam ID: PF04840) mediates binding to Vps33 proteins (Baker et al. 2013; Graham et al. 2013). These belong to the Sec1/Munc18 (SM) protein family (Misura et al. 2000; Graham et al. 2013) and have three domains, arranged in an arch-like structure, with an internal cavity capable of binding to SNARE proteins (Misura et al. 2000; Baker et al. 2013; Toonen and Verhage 2003; Baker et al. 2015). SM proteins bind to SNARE proteins such as syntaxin and are important for membrane fusion in disparate pathways, including synapse neurotransmitter release (Wu et al. 1998; Harrison et al. 1994; Weimer and Richmond 2004), early endosomal tracking (Nielsen et al. 2000) (Morrison et al. 2008) and Golgi-ER tracking (Laufman et al. 2009). However, their precise role is not fully understood.

Humans and flies have two Vps16 proteins: Vps16a, which binds to Vps33a in the HOPS and CORVET complexes that promote fusion of endosomes or autophagosome to lysosomes (Bröcker et al. 2012; Urban et al. 2012; Solinger and Spang 2013), and Vps16b, which binds to Vps33b in the analogous but smaller CHEVI complex (Hunter et al. 2018; van der Beek et 
al. 2019). Therefore, the Spg11-C-terminal domain could potentially also bind to SM proteins; its divergence from known Vps16_C domains, and the relatively low conservation of Vps16 residues that bind to Vps33a, suggest that it is unlikely to bind to Vps33a or Vps33b, but it could potentially bind to other SM family proteins. The localization of the Spg11 C-terminus to acidic compartments (Figure 4A) could indicate a role for the Spg11-C-terminus in regulating some membrane fusion event(s) involving late endosomes, autophagosomes, autolysosomes, or lysosomes.

SPG11 C-terminus interacts with SM proteins Rop, SIh and Vps45. Mass spectrometry analysis of the SPG11 C-terminus expressed in Drosophila Mel-2 cells was used to identify potential binding partners of the Spg11 C-terminus. This identified three of the five Drosophila SM proteins: Rop, SIh and Vps45, which were not found in the negative GFP control, tentatively indicating that the Spg11 C-terminus may possess SM protein binding ability.

Of the SM proteins identified, Rop was the highest scoring (Table 7). Rop is the homologue of yeast Sec1p (Wu et al. 1998), and is involved in synaptic vesicle exocytosis, synapse transmission and secretion (Wu et al. 1998; Harrison et al. 1994; Weimer and Richmond 2004); it does not appear to bind to Vps16a or Vps16b in Drosophila (Pulipparacharuvil et al. 2005). Vps45 is important in the endocytic pathway (Nielsen et al. 2000; Morrison et al. 2008). In both humans and flies, Vps45 is part of a complex with Rab5 and a FYVE-containing protein, Rabenosyn-5, to mediate vesicle fusion to form early endosomes (Nielsen et al. 2000; Morrison et al. 2008). In humans VPS45 mutations are associated with congenital neutropenia, with human VPS45 patients lacking lysosomes (Stepensky et al. 2013). Slh is the orthologue of yeast Sly1 (Toonen and Verhage 2003). In mammals, Sly1 is implicated in Golgi-to-ER retrograde transport (Laufman et al. 2009; Nogueira et al. 2014). At this stage we cannot tell whether the SM protein interactions of the Spatacsin_C domain are direct, or of functional biological significance. However, they do occur in a native Drosophila cellular environment, and they are therefore consistent with the model of a Vps16_C-like function for the Spatacsin_C domain.

The Spg11 C-terminus interacts with aminoacyl tRNA synthetases. Mass spectrometry of GFP::Spg11-C pulled down five aminoacyl-tRNA (aa-tRNA) synthetases (Figure 6A), The aatRNA synthetases are essential for normal protein translation, by attaching the correct amino acid onto cognate tRNA molecules (Cusack 1997; Wallen and Antonellis 2013; Datta et al. 2009; Swairjo et al. 2004). However, mutations in at least two human aa-tRNA synthetases identified here, MARS and AARS, cause the axonal neuropathy, dominant Charcot-MarieTooth disease, type 2 (McLaughlin et al. 2012; Timmerman et al. 2014); furthermore, loss-of- 
function mutations in SPG11 (Montecchiani et al. 2016); as well as mutations in the Spg11 binding partner, Rab7 (Gillingham et al. 2014), can cause CMT type 2 (Cogli et al. 2009). Therefore, mutations affecting SPG11, Rab7, and aa-tRNA synthetases might cause CharcotMarie-Tooth disease by a common mechanism.

What kind of common mechanism could this be? CMT2 causality of aa-tRNA synthetases is a dominant trait that may be due to exposure of an internal surface by CMT2 mutations, and is independent of their enzymatic activity (Blocquel et al. 2017); the resulting dominant neurological CMT2 disease phenotype resembles an SPG11 recessive phenotype, suggesting that either SPG11 protein or aa-tRNA synthetases might antagonize each other. Aminoacyl tRNA synthetases have functions beyond translation, including amino acid sensing and autophagy regulation, by mediating mTOR activation (Han et al. 2012; Bonfils et al. 2012; Jewell et al. 2013). Further, when HeLa cells are treated with Leucine, LARS translocates to the lysosomal membrane where it acts as a GTPase-activating protein (GAP) for Rag GTPase (Han et al. 2012; Bonfils et al. 2012). Since SPG11 functions on autolysosomes to regenerate lysosomes, it could interact with aa-tRNA synthetases there. We therefore hypothesize that CMT2 pathology could be caused by defects in autophagosomal lysosome reformation as occurs in SPG11 loss-of-function (Varga et al. 2015), or by defects in lysosomal amino-acidsensing machinery caused by gain-of-function mutations in aminoacyl-tRNA synthetases.

Conclusions. Our analyses suggest that the sole essential function of the $\mathrm{N}$-terminus of SPG11 is to bind the AP-5 adaptor complex, and support the model that its C-terminal spatacsin_C domain is a distantly related Vps_C domain, with roles in membrane trafficking. The recovery of several aminoacyl-tRNA synthetases as binding partners of this domain, suggests the possibility that mutations in human SPG11 or in aminoacyl-tRNA synthetases could give rise to Charcot-Marie-Tooth axonopathy by affecting a common cellular process in membrane trafficking.

Acknowledgements. We thank Yuu Kimata and his group for help with Drosophila cell culture and establishment of cell lines, and the Drosophila Genomics Resource Center (supported by NIH Grant 2P40OD010949) for plasmids. This work was funded by a PhD studentship 861792 from the UK Motor Neuron Disease Association and the Le Bouedec family to ALP, and by a grant from the Tom-Wahlig Stiftung to CJO'K. 


\section{References}

Anheim M., Lagier-Tourenne C., Stevanin G., Fleury M., Durr A., Namer I. J., Denora P., et al. (2009) SPG11 spastic paraplegia: A new cause of juvenile parkinsonism. J. Neurol. 256, 104-108.

Baker R. W., Jeffrey P. D., Hughson F. M. (2013) Crystal Structures of the Sec1/Munc18 (SM) Protein Vps33, Alone and Bound to the Homotypic Fusion and Vacuolar Protein Sorting (HOPS) Subunit Vps16*. PLoS One 8.

Baker R. W., Jeffrey P. D., Zick M., Phillips B. P., Wickner W. T., Hughson F. M. (2015) A direct role for the Sec1/Munc18-family protein Vps33 as a template for SNARE assembly. Science (80-. ). 349, 1111-1114.

Beek J. van der, Jonker C., Welle R. van der, Liv N., Klumperman J. (2019) CORVET, CHEVI and HOPS - Multisubunit tethers of the endo-lysosomal system in health and disease.

Blocquel D., Li S., Wei N., Daub H., Sajish M., Erfurth M. L., Kooi G., et al. (2017) Alternative stable conformation capable of protein misinteraction links tRNA synthetase to peripheral neuropathy. Nucleic Acids Res. 45, 8091-8104.

Bonfils G., Jaquenoud M., Bontron S., Ostrowicz C., Ungermann C., Virgilio C. De (2012) Leucyl-tRNA Synthetase Controls TORC1 via the EGO Complex. Mol. Cell 46, 105110.

Boukhris A., Stevanin G., Feki I., Denis E., Elleuch N., Miladi M. I., Truchetto J., et al. (2008) Hereditary spastic paraplegia with mental impairment and thin corpus callosum in Tunisia: SPG11, SPG15, and further genetic heterogeneity. Arch. Neurol. 65, 393-402.

Bröcker C., Kuhlee A., Gatsogiannis C., Kleine Balderhaar H. J., Hönscher C., EngelbrechtVandré S., Ungermann C., Raunser S. (2012) Molecular architecture of the multisubunit homotypic fusion and vacuole protein sorting (HOPS) tethering complex. Proc. Natl. Acad. Sci. U. S. A. 109, 1991-1996.

Chang J., Lee S., Blackstone C. (2014) Spastic paraplegia proteins spastizin and spatacsin mediate autophagic lysosome reformation. J. Clin. Invest. 124, 5249-5262.

Cogli L., Piro F., Bucci C. (2009) Rab7 and the CMT2B disease, in Biochem. Soc. Trans., Vol. 37, pp. 1027-1031.

Cusack S. (1997) Aminoacyl-tRNA synthetases. Curr. Opin. Struct. Biol. 7, 881-889.

Daoud H., Zhou S., Noreau A., Sabbagh M., Belzil V., Dionne-Laporte A., Tranchant C., Dion P., Rouleau G. A. (2012) Exome sequencing reveals SPG11 mutations causing juvenile ALS. Neurobiol. Aging 33, 839.e5-839.e9.

Datta D., Vaidehi N., Zhang D., Goddard W. A. (2009) Selectivity and specificity of substrate binding in methionyl-tRNA synthetase. Protein Sci. 13, 2693-2705.

Edgar R. C. (2004) MUSCLE: Multiple sequence alignment with high accuracy and high throughput. Nucleic Acids Res. 32, 1792-1797.

Fridman V., Murphy S. M. (2014) The spectrum of axonopathies: From CMT2 to HSP.

Gillingham A. K., Sinka R., Torres I. L., Lilley K. S., Munro S. (2014) Toward a Comprehensive Map of the Effectors of Rab GTPases. Dev. Cell 31, 358.

Gonzalez M., McLaughlin H., Houlden H., Guo M., Liu Y. T., Hadjivassilious M., Speziani F., et al. (2013) Exome sequencing identifies a significant variant in methionyl-tRNA synthetase (MARS) in a family with late-onset CMT2. J. Neurol. Neurosurg. Psychiatry 84, 1247-1249.

Graham S. C., Wartosch L., Gray S. R., Scourfield E. J., Deane J. E., Luzio J. P., Owen D. J. 
(2013) Structural basis of Vps33A recruitment to the human HOPS complex by Vps16. Proc. Natl. Acad. Sci. U. S. A. 110, 13345-13350.

Guidubaldi A., Piano C., Santorelli F. M., Silvestri G., Petracca M., Tessa A., Bentivoglio A. R. (2011) Novel mutations in SPG11 cause hereditary spastic paraplegia associated with early-onset levodopa-responsive Parkinsonism. Mov. Disord. 26, 553-556.

Han J. M., Jeong S. J., Park M. C., Kim G., Kwon N. H., Kim H. K., Ha S. H., Ryu S. H., Kim S. (2012) Leucyl-tRNA synthetase is an intracellular leucine sensor for the mTORC1signaling pathway. Cell 149, 410-424.

Harrison S. D., Broadie K., Goor J. van de, Rubin G. M. (1994) Mutations in the drosophila Rop gene suggest a function in general secretion and synaptic transmission. Neuron 13, 555-566.

Hirst J., Barlow L., Francisco G. C., Sahlender D. A., Seaman M. N. J., Dacks J. B., Robinson M. S. (2011) The fifth adaptor protein complex. PLoS Biol. 9.

Hirst J., Borner G. H. H., Antrobus R., Peden A. A., Hodson N. A., Sahlender D. A., Robinson M. S. (2012) Distinct and overlapping roles for AP-1 and GGAs revealed by the "knocksideways" system. Curr. Biol. 22, 1711-1716.

Hirst J., Borner G. H. H., Edgar J., Hein M. Y., Mann M., Buchholz F., Antrobus R., Robinson M. S. (2013) Interaction between AP-5 and the hereditary spastic paraplegia proteins SPG11 and SPG15. Mol. Biol. Cell 24, 2558-2569.

Hirst J., Itzhak D. N., Antrobus R., Borner G. H. H., Robinson M. S. (2018) Role of the AP-5 adaptor protein complex in late endosome-to-Golgi retrieval. PLoS Biol. 16.

Hirst J., Madeo M., Smets K., Edgar J. R., Schols L., Li J., Yarrow A., et al. (2016) Complicated spastic paraplegia in patients with AP5Z1 mutations (SPG48). Neurol. Genet. 2.

Hunter M. R., Hesketh G. G., Benedyk T. H., Gingras A. C., Graham S. C. (2018) Proteomic and Biochemical Comparison of the Cellular Interaction Partners of Human VPS33A and VPS33B. J. Mol. Biol. 430, 2153-2163.

Jewell J. L., Russell R. C., Guan K. L. (2013) Amino acid signalling upstream of mTOR. Nat. Rev. Mol. Cell Biol. 14, 133-139.

Kim B. Y., Krämer H., Yamamoto A., Kominami E., Kohsaka S., Akazawa C. (2001) Molecular Characterization of Mammalian Homologues of Class C Vps Proteins That Interact with Syntaxin-7. J. Biol. Chem. 276, 29393-29402.

Lassmann T., Sonnhammer E. L. L. (2005) Kalign - An accurate and fast multiple sequence alignment algorithm. BMC Bioinformatics 6.

Laufman O., Kedan A., Hong W., Lev S. (2009) Direct interaction between the COG complex and the SM protein, Sly1, is required for Golgi SNARE pairing. EMBO J. 28, 20062017.

Martin E., Yanicostas C., Rastetter A., Naini S. M. A., Maouedj A., Kabashi E., RivaudPéchoux S., Brice A., Stevanin G., Soussi-Yanicostas N. (2012) Spatacsin and spastizin act in the same pathway required for proper spinal motor neuron axon outgrowth in zebrafish. Neurobiol. Dis. 48, 299-308.

Mauvezin C., Ayala C., Braden C. R., Kim J., Neufeld T. P. (2014) Assays to monitor autophagy in Drosophila. Methods 68, 134-139.

McLaughlin H. M., Sakaguchi R., Giblin W., Wilson T. E., Biesecker L., Lupski J. R., Talbot K., et al. (2012) A recurrent loss-of-function alanyl-tRNA synthetase (AARS) mutation in patients with charcot-marie-tooth disease type 2N (CMT2N). Hum. Mutat. 33, 244-253.

Misura K. M. S., Scheller R. H., Weis W. I. (2000) Three-dimensional structure of the 
neuronal-Sec1-syntaxin 1a complex.

Montecchiani C., Pedace L., Giudice T. Lo, Casella A., Mearini M., Gaudiello F., Pedroso J. L., et al. (2016) ALS5/SPG11/KIAA1840 mutations cause autosomal recessive axonal Charcot-Marie-Tooth disease. Brain 139, 73-85.

Morrison H. A., Dionne H., Rusten T. E., Brech A., Fisher W. W., Pfeiffer B. D., Celniker S. E., Stenmark H., Bilder D. (2008) RegUlation of Early Endosomal Entry by the Drosophila tumor suppressors rabenosyn and Vps45. Mol. Biol. Cell 19, 4167-4176.

Murmu R. P., Martin E., Rastetter A., Esteves T., Muriel M. P., Hachimi K. H. El, Denora P. S., et al. (2011) Cellular distribution and subcellular localization of spatacsin and spastizin, two proteins involved in hereditary spastic paraplegia. Mol. Cell. Neurosci. 47, 191-202.

Nielsen E., Christoforidis S., Uttenweiler-Joseph S., Miaczynska M., Dewitte F., Wilm M., Hoflack B., Zerial M. (2000) Rabenosyn-5, a novel Rab5 effector, is complexed with hVPS45 and recruited to endosomes through a FYVE finger domain. J. Cell Biol. 151, 601-612.

Nogueira C., Erlmann P., Villeneuve J., Santos A. J. M., Martinez-Alonso E., MartínezMenárguez J. Á., Malhotra V. (2014) SLY1 and syntaxin 18 specify a distinct pathway for procollagen VII export from the endoplasmic reticulum. Elife 2014.

Orlacchio A., Babalini C., Borreca A., Patrono C., Massa R., Basaran S., Munhoz R. P., et al. (2010) SPATACSIN mutations cause autosomal recessive juvenile amyotrophic lateral sclerosis. Brain 133, 591-598.

Pensato V., Castellotti B., Gellera C., Pareyson D., Ciano C., Nanetti L., Salsano E., et al. (2014) Overlapping phenotypes in complex spastic paraplegias SPG11, SPG15, SPG35 and SPG48. Brain 137, 1907-1920.

Pérez-Brangulí F., Mishra H. K., Prots I., Havlicek S., Kohl Z., Saul D., Rummel C., et al. (2014) Dysfunction of spatacsin leads to axonal pathology in SPG11-linked hereditary spastic paraplegia. Hum. Mol. Genet. 23, 4859-4874.

Pulipparacharuvil S., Akbar M. A., Ray S., Sevrioukov E. A., Haberman A. S., Rohrer J., Krämer H. (2005) Drosophila Vps16A is required for trafficking to lysosomes and biogenesis of pigment granules. J. Cell Sci. 118, 3663-3673.

Renvoisé B., Chang J., Singh R., Yonekawa S., FitzGibbon E. J., Mankodi A., Vanderver A., et al. (2014) Lysosomal abnormalities in hereditary spastic paraplegia types SPG15 and SPG11. Ann. Clin. Transl. Neurol. 1, 379-389.

Rohrer J., Schweizer A., Russell D., Kornfeld S. (1996) The targeting of lamp1 to lysosomes is dependent on the spacing of its cytoplasmic tail tyrosine sorting motif relative to the membrane. J. Cell Biol. 132, 565-576.

Schneider I. (1972) Cell lines derived from late embryonic stages of Drosophila melanogaster. J. Embryol. Exp. Morphol. 27, 353-365.

Schröder B., Wrocklage C., Pan C., Jäger R., Kösters B., Schäfer H., Elsässer H. P., Mann M., Hasilik A. (2007) Integral and associated lysosomal membrane proteins. Traffic 8, 1676-1686.

Słabicki M., Theis M., Krastev D. B., Samsonov S., Mundwiller E., Junqueira M., PaszkowskiRogacz M., et al. (2010) A genome-scale DNA repair RNAi screen identifies SPG48 as a novel gene associated with hereditary spastic paraplegia. PLoS Biol. 8.

Söding J., Biegert A., Lupas A. N. (2005) The HHpred interactive server for protein homology detection and structure prediction. Nucleic Acids Res. 33.

Solinger J. A., Spang A. (2013) Tethering complexes in the endocytic pathway: CORVET 
and HOPS.

Stepensky P., Saada A., Cowan M., Tabib A., Fischer U., Berkun Y., Saleh H., et al. (2013) The Thr224Asn mutation in the VPS45 gene is associated with the congenital neutropenia and primary myelofibrosis of infancy. Blood 121, 5078-5087.

Stevanin G., Santorelli F. M., Azzedine H., Coutinho P., Chomilier J., Denora P. S., Martin E., et al. (2007) Mutations in SPG11, encoding spatacsin, are a major cause of spastic paraplegia with thin corpus callosum. Nat. Genet. 39, 366-372.

Swairjo M. A., Otero F. J., Yang X. L., Lovato M. A., Skene R. J., McRee D. E., Pouplana L. R. De, Schimmel P. (2004) Alanyl-tRNA synthetase crystal structure and design for acceptor-stem recognition. Mol. Cell 13, 829-841.

Szymanski C. J., Humphries IV W. H., Payne C. K. (2011) Single particle tracking as a method to resolve differences in highly colocalized proteins. Analyst 136, 3527-3533.

Timmerman V., Strickland A. V., Züchner S. (2014) Genetics of Charcot-Marie-Tooth (CMT) disease within the frame of the human genome project success.

Toonen R. F. G., Verhage M. (2003) Vesicle trafficking: Pleasure and pain from SM genes.

Urban D., Li N., Christensen H., Pluthero F. G., Chen S. Z., Puhacz M., Garg P. M., et al. (2012) The VPS33B-binding protein VPS16B is required in megakaryocyte and platelet a-granule biogenesis. Blood 120, 5032-5040.

Vantaggiato C., Crimella C., Airoldi G., Polishchuk R., Bonato S., Brighina E., Scarlato M., et al. (2013) Defective autophagy in spastizin mutated patients with hereditary spastic paraparesis type 15. Brain 136, 3119-3139.

Varga R. E., Khundadze M., Damme M., Nietzsche S., Hoffmann B., Stauber T., Koch N., et al. (2015) In Vivo Evidence for Lysosome Depletion and Impaired Autophagic Clearance in Hereditary Spastic Paraplegia Type SPG11. PLoS Genet. 11.

Wallen R. C., Antonellis A. (2013) To charge or not to charge: Mechanistic insights into neuropathy-associated tRNA synthetase mutations.

Wartosch L., Günesdogan U., Graham S. C., Luzio J. P. (2015) Recruitment of VPS33A to HOPS by VPS16 Is Required for Lysosome Fusion with Endosomes and Autophagosomes. Traffic 16, 727-742.

Webb B., Sali A. (2016) Comparative protein structure modeling using MODELLER. Curr. Protoc. Bioinforma. 2016, 5.6.1-5.6.37.

Wei N., Zhang Q., Yang X. L. (2019) Neurodegenerative Charcot-Marie-Tooth disease as a case study to decipher novel functions of aminoacyl-tRNA synthetases. J. Biol. Chem. 294, 5321-5339.

Weimer R. M., Richmond J. E. (2004) Synaptic Vesicle Docking: A Putative Role for the Munc18\{plus 45 degree rule\}Sec1 Protein Family. Curr. Top. Dev. Biol. 65, 83-113.

Wu M. N., Littleton J. T., Bhat M. A., Prokop A., Bellen H. J. (1998) ROP, the Drosophila Sec1 homolog, interacts with syntaxin and regulates neurotransmitter release in a dosage-dependent manner. EMBO J. 17, 127-139.

Yu L., McPhee C. K., Zheng L., Mardones G. A., Rong Y., Peng J., Mi N., et al. (2010) Termination of autophagy and reformation of lysosomes regulated by mTOR. Nature 465, 942-946.

Zhao W., Zhu Q. Y., Zhang J. T., Liu H., Wang L. J., Chen Z. Q., Guan L. P., Huang X. S., Yang L., Yu S. Y. (2013) Exome sequencing identifies novel compound heterozygous mutations in SPG11 that cause autosomal recessive hereditary spastic paraplegia. $J$. Neurol. Sci. 335, 112-117. 
bioRxiv preprint doi: https://doi.org/10.1101/2020.03.08.982389; this version posted September 13,2020 . The copyright holder for this preprint (which was not certified by peer review) is the author/funder, who has granted bioRxiv a license to display the preprint in perpetuity. It is made available under aCC-BY-NC 4.0 International license.

Zimmermann L., Stephens A., Nam S. Z., Rau D., Kübler J., Lozajic M., Gabler F., Söding J., Lupas A. N., Alva V. (2018) A Completely Reimplemented MPI Bioinformatics Toolkit with a New HHpred Server at its Core. J. Mol. Biol. 430, 2237-2243. 
Table 1. Top 100 unique hits found in mass spectrometry output from GFP::Spg11-C purification from PMT-GFP::Spg11-C. Biological process and human ortholog (Human Ortho) data are from Flybase (www.flybase.org). Some of the hits discussed in the text are in bold.

\begin{tabular}{|c|c|c|c|c|c|c|c|c|}
\hline Gene & Protein & CDS & Score & $\left|\begin{array}{l}\text { Matc } \\
\text { hes }\end{array}\right|$ & $\begin{array}{l}\text { Seq } \\
\text { uen } \\
\text { ces }\end{array}$ & Biological Process & Cellular Component & $\begin{array}{l}\text { Human } \\
\text { Ortho }\end{array}$ \\
\hline CG13531 & CG13531 & PB & 14611 & 290 & & 7 axon extension & axon & SPG11 \\
\hline CG11700 & CG11700 & PB & 1876 & 82 & & 5 protein ubiquitination & $\begin{array}{l}\text { microtubule associated } \\
\text { complex }\end{array}$ & RPS27A \\
\hline deltaCOP & CG14813 & PA & 1813 & 41 & & $\begin{array}{l}3 \text { retrograde vesicle-mediated } \\
\text { transport, Golgi to ER }\end{array}$ & COPI vesicle coat & ARCN1 \\
\hline CG30109 & CG30109 & PB & 1771 & 27 & & 3 biological_process & cellular_component & TRIAP1 \\
\hline Cisd2 & CG1458 & PA & 1630 & 28 & & 3 biological_process & $\begin{array}{l}\text { intracellular membrane- } \\
\text { bounded organelle }\end{array}$ & CISD2 \\
\hline Prx2540-2 & CG11765 & PA & 1604 & 51 & & 1 cell redox homeostasis & cytosol & PRDX6 \\
\hline $\operatorname{Prx} 2540-1$ & CG12405 & PA & 1430 & 47 & & $\begin{array}{l}0 \text { hydrogen peroxide catabolic } \\
\text { process }\end{array}$ & cytosol & PRDX6 \\
\hline CG12896 & CG12896 & PA & 1193 & 40 & & 9 mesoderm development & cytoplasm & PRDX6 \\
\hline Dgp-1 & CG5729 & PA & 1192 & 25 & & 0 biological_process & cellular_component & GTPBP1 \\
\hline Rep & CG8432 & PA & 1192 & 25 & & 8 neurotransmitter secretion & $\begin{array}{l}\text { Rab-protein } \\
\text { geranylgeranyltransferase } \\
\text { complex }\end{array}$ & $\mathrm{CHM}$ \\
\hline MetRS & CG15100 & PA & 1147 & 26 & & 4 methionyl-tRNA aminoacylation & $\begin{array}{l}\text { microtubule associated } \\
\text { complex }\end{array}$ & MARS \\
\hline Aldh-III & CG11140 & PE & 1087 & 25 & & 0 oxidation-reduction process & lipid particle & GK5 \\
\hline $\begin{array}{l}\text { Prosalpha } \\
2\end{array}$ & CG5266 & PA & 1053 & 21 & & $\begin{array}{l}5 \text { proteasome-mediated ubiquitin- } \\
\text { dependent protein catabolic } \\
\text { process }\end{array}$ & proteasome core complex & PSMA7 \\
\hline mys & CG1560 & PA & 969 & 23 & & $\begin{array}{l}7 \text { central nervous system } \\
\text { development }\end{array}$ & focal adhesion & ITGB8 \\
\hline mys & CG1560 & PB & 916 & 21 & & $\begin{array}{l}6 \text { central nervous system } \\
\text { development }\end{array}$ & focal adhesion & ITGB8 \\
\hline $\mathrm{su}(\mathrm{r})$ & CG2194 & $\mathrm{PC}$ & 913 & 18 & & $\begin{array}{l}1 \text { 'de novo' pyrimidine nucleobase } \\
\text { biosynthetic process }\end{array}$ & cytoplasm & DPYD \\
\hline eEF1delta & CG4912 & PA & 892 & 16 & & 5 translational elongation & $\begin{array}{l}\text { eukaryotic translation } \\
\text { elongation factor } 1 \text { complex }\end{array}$ & EEF1D \\
\hline Msp300 & CG42768 & PG & 797 & 18 & & 5 mesoderm development & actin cytoskeleton & SYNE2 \\
\hline Msp300 & CG42768 & PD & 796 & 17 & & 4 mesoderm development & actin cytoskeleton & SYNE2 \\
\hline Hsp27 & CG4466 & PA & 794 & 14 & & 3 determination of adult lifespan & $\begin{array}{l}\text { microtubule associated } \\
\text { complex }\end{array}$ & HSPB6 \\
\hline elF4G & CG10811 & PA & 741 & 19 & & 3 translational initiation & cytosol & EIF4G1 \\
\hline smid & CG8571 & PA & 710 & 11 & & 5 neurogenesis & - & NVL \\
\hline Usp14 & CG5384 & PA & 700 & 10 & & $\begin{array}{l}5 \text { ubiquitin-dependent protein } \\
\text { catabolic process }\end{array}$ & $\begin{array}{l}\text { microtubule associated } \\
\text { complex }\end{array}$ & USP14 \\
\hline $\begin{array}{l}\text { Prosalpha } \\
3\end{array}$ & CG9327 & PA & 682 & 16 & & $\begin{array}{l}5 \text { ubiquitin-dependent protein } \\
\text { catabolic process }\end{array}$ & cytoplasm & PSMA4 \\
\hline CG8005 & CG8005 & PA & 675 & 16 & & $\begin{array}{l}6 \text { peptidyl-lysine modification to } \\
\text { peptidyl-hypusine }\end{array}$ & - & DHPS \\
\hline$r$ & CG18572 & PA & 652 & 17 & & $\begin{array}{l}2 \text { 'de novo' pyrimidine nucleobase } \\
\text { biosynthetic process }\end{array}$ & cytoplasm & CPS1 \\
\hline CG17514 & CG17514 & PA & 651 & 18 & & 3 regulation of translation & - & GCN1 \\
\hline Tango7 & CG8309 & PA & 632 & 15 & & 7 Golgi organization & Golgi apparatus & EIF3M \\
\hline Rpn5 & CG1100 & PA & 627 & 19 & & $\begin{array}{l}9 \text { proteasome-mediated ubiquitin- } \\
\text { dependent protein catabolic } \\
\text { process }\end{array}$ & $\begin{array}{l}\text { proteasome regulatory } \\
\text { particle }\end{array}$ & PSMD12 \\
\hline nop5 & CG10206 & PA & 605 & 12 & & 7 rRNA processing & nucleolus & NOP58 \\
\hline Ts & CG3181 & PA & 591 & 7 & & $\begin{array}{l}3 \text { deoxyribonucleotide biosynthetic } \\
\text { process }\end{array}$ & - & TYMS \\
\hline Cp1 & CG6692 & PA & 590 & 15 & & 4 protein catabolic process & lysosome & CTSS \\
\hline Mrp4 & CG14709 & PB & 588 & 13 & & 9 drug transmembrane transport & $\begin{array}{l}\text { ATP-binding cassette }(A B C) \\
\text { transporter complex }\end{array}$ & $\mathrm{ABCC} 4$ \\
\hline Dhc64C & CG7507 & PA & 582 & 14 & & 1 cellularization & cytoplasm & DYNC1H1 \\
\hline rhea & CG6831 & PB & 526 & 13 & & $\begin{array}{l}9 \text { cytoskeletal anchoring at plasma } \\
\text { membrane }\end{array}$ & focal adhesion & TLN2 \\
\hline
\end{tabular}




\begin{tabular}{|c|c|c|c|c|c|c|c|}
\hline CG7945 & CG7945 & PA & 524 & 9 & 5 protein folding & - & BAG2 \\
\hline poe & CG14472 & PA & 519 & 15 & 12 spermatid development & $P$ granule & UBR4 \\
\hline CG7945 & CG7945 & PB & 510 & 8 & 4 protein folding & - & BAG2 \\
\hline msk & CG7935 & PA & 475 & 10 & 6 protein import into nucleus & cytoplasm & IPO7 \\
\hline CG10289 & CG10289 & PA & 474 & 9 & $7-$ & - & \\
\hline ade5 & CG3989 & PA & 461 & 11 & 6 inter-male aggressive behavior & cytoplasm & PAICS \\
\hline hts & CG43443 & PA & 452 & 8 & 5 axon guidance & lipid particle & \\
\hline Rpt6R & CG2241 & PA & 440 & 14 & 5 neurogenesis & $\begin{array}{l}\text { microtubule associated } \\
\text { complex }\end{array}$ & PSMC2 \\
\hline $\begin{array}{l}\text { Prosalpha } \\
4\end{array}$ & CG3422 & PA & 434 & 10 & $\begin{array}{l}4 \text { cellular response to DNA damage } \\
\text { stimulus }\end{array}$ & $\begin{array}{l}\text { microtubule associated } \\
\text { complex }\end{array}$ & PSMA7 \\
\hline Rpn7 & CG5378 & PA & 420 & 10 & 4 proteolysis & $\begin{array}{l}\text { proteasome regulatory } \\
\text { particle, lid subcomplex }\end{array}$ & PSMD6 \\
\hline pic & CG7769 & PA & 418 & 16 & $\begin{array}{l}6 \text { positive regulation of protein } \\
\text { catabolic process }\end{array}$ & nucleus & DDB1 \\
\hline Cand1 & CG5366 & PA & 415 & 6 & 3 regulation of protein stability & - & CAND1 \\
\hline $\begin{array}{l}\text { Prosalpha } \\
6\end{array}$ & CG4904 & PB & 409 & 12 & $\begin{array}{l}6 \text { proteasome-mediated ubiquitin- } \\
\text { dependent protein catabolic } \\
\text { process }\end{array}$ & cytoplasm & PSMA1 \\
\hline FKBP59 & CG4535 & PA & 402 & 12 & $\begin{array}{l}6 \text { peripheral nervous system } \\
\text { development }\end{array}$ & inaD signaling complex & FKBP5 \\
\hline kcc & CG5594 & PE & 391 & 8 & 5 transport & $\begin{array}{l}\text { integral component of } \\
\text { membrane }\end{array}$ & SLC12A5 \\
\hline elF-2beta & CG4153 & PA & 388 & 7 & 2 translational initiation & cytosol & EIF2S2 \\
\hline Uch-L5 & CG3431 & PA & 382 & 12 & 5 protein deubiquitination & $\begin{array}{l}\text { proteasome regulatory } \\
\text { particle }\end{array}$ & UCHL5 \\
\hline Rab35 & CG9575 & PA & 379 & 12 & 3 mitotic cytokinesis & lipid particle & RAB8B \\
\hline Int6 & CG9677 & PA & 376 & 9 & 5 translational initiation & $\begin{array}{l}\text { eukaryotic translation } \\
\text { initiation factor } 3 \text { complex }\end{array}$ & EIF3E \\
\hline CG31918 & CG31918 & PA & 375 & 10 & 6 proteolysis & - & PHEX \\
\hline Mfe2 & CG3415 & PA & 368 & 7 & $\begin{array}{l}4 \text { fatty acid beta-oxidation using } \\
\text { acyl-CoA oxidase }\end{array}$ & peroxisome & HSD17B4 \\
\hline ND-75 & CG2286 & PA & 362 & 10 & 8 cellular respiration & $\begin{array}{l}\text { mitochondrial respiratory } \\
\text { chain complex I }\end{array}$ & NDUFS1 \\
\hline Pect & CG5547 & PB & 362 & 12 & $\begin{array}{l}7 \text { ethanolamine-containing } \\
\text { compound metabolic process }\end{array}$ & - & PCYT2 \\
\hline MAPk-Ak2 & CG3086 & PB & 360 & 9 & 4 protein phosphorylation & cytoplasm & MAPKAPK5 \\
\hline $\begin{array}{l}\text { Prosalpha } \\
7\end{array}$ & CG1519 & PA & 358 & 11 & $\begin{array}{l}6 \text { cellular response to DNA damage } \\
\text { stimulus }\end{array}$ & $\begin{array}{l}\text { microtubule associated } \\
\text { complex }\end{array}$ & PSMA3 \\
\hline I(1)G0193 & CG2206 & PA & 355 & 7 & 6 biological_process & cellular_component & \\
\hline Ugt & CG6850 & PA & 348 & 4 & 4 protein glycosylation & cytoplasm & UGGT1 \\
\hline Rab4 & CG4921 & PB & 347 & 8 & $\begin{array}{l}2 \text { ovarian follicle cell-cell } \\
\text { adhesion }\end{array}$ & synapse & RAB4B \\
\hline MtnA & CG9470 & PA & 346 & 10 & 2 response to metal ion & cellular_component & \\
\hline CG10527 & CG10527 & PA & 344 & 11 & $4-$ & cytoplasm & \\
\hline grsm & CG7340 & PB & 344 & 7 & 4 proteolysis & cytoplasm & NPEPL1 \\
\hline kcc & CG5594 & $\mathrm{PC}$ & 343 & 6 & 4 transport & $\begin{array}{l}\text { integral component of } \\
\text { membrane }\end{array}$ & SLC12A5 \\
\hline UQCR-14 & CG3560 & PA & 342 & 10 & $\begin{array}{l}5 \text { mitochondrial electron transport, } \\
\text { ubiquinol to cytochrome c }\end{array}$ & $\begin{array}{l}\text { mitochondrial respiratory } \\
\text { chain complex III }\end{array}$ & UQCRB \\
\hline SerRS & CG17259 & PA & 341 & 6 & 4 seryl-tRNA aminoacylation & cytoplasm & SARS \\
\hline rump & CG9373 & PA & 340 & 9 & $\begin{array}{l}3 \text { anterior/posterior axis } \\
\text { specification, embryo }\end{array}$ & nuclear chromatin & MYEF2 \\
\hline smt3 & CG4494 & PA & 337 & 6 & 2 phagocytosis & nucleus & SUMO2 \\
\hline PpD3 & CG8402 & PB & 330 & 5 & 3 protein dephosphorylation & nucleus & PPP5C \\
\hline rush & CG14782 & PA & 329 & 10 & $\begin{array}{l}4 \text { neuron projection } \\
\text { morphogenesis }\end{array}$ & early endosome & PLEKHF1 \\
\hline CG9674 & CG9674 & PA & 323 & 8 & 6 oxidation-reduction process & - & FDXR \\
\hline CG1598 & CG1598 & PA & 320 & 6 & $3-$ & - & ASNA1 \\
\hline CG32576 & CG32576 & PA & 320 & 3 & 1 vesicle-mediated transport & cellular_component & GOLT1B \\
\hline Сур9c1 & CG3616 & PA & 319 & 5 & 4 oxidation-reduction process & membrane & CYP4F12 \\
\hline $\begin{array}{l}\text { Prosalpha } \\
5\end{array}$ & CG10938 & PA & 317 & 11 & $\begin{array}{l}5 \text { proteasome-mediated ubiquitin- } \\
\text { dependent protein catabolic } \\
\text { process }\end{array}$ & $\begin{array}{l}\text { proteasome core complex, } \\
\text { alpha-subunit complex }\end{array}$ & PSMA5 \\
\hline Cklalpha & CG2028 & PB & 315 & 6 & 3 DNA repair & cytoplasm & CSNK1A1L \\
\hline Mi-2 & CG8103 & PA & 307 & 5 & $\begin{array}{l}3 \text { negative regulation of cohesin } \\
\text { loading }\end{array}$ & nucleus & CHD3 \\
\hline
\end{tabular}


bioRxiv preprint doi: https://doi.org/10.1101/2020.03.08.982389; this version posted September 13, 2020. The copyright holder for this preprint (which was not certified by peer review) is the author/funder, who has granted bioRxiv a license to display the preprint in perpetuity. It is made available under aCC-BY-NC 4.0 International license.

\begin{tabular}{|c|c|c|c|c|c|c|c|}
\hline CG40045 & CG40045 & PA & 305 & 8 & 2 protein polyubiquitination & cellular_component & CDC34 \\
\hline Rpn12 & CG4157 & PA & 300 & 5 & 3 neurogenesis & $\begin{array}{l}\text { proteasome regulatory } \\
\text { particle }\end{array}$ & PSMD8 \\
\hline Sgt & CG5094 & PA & 297 & 9 & $\begin{array}{l}5 \text { neuromuscular synaptic } \\
\text { transmission }\end{array}$ & cellular_component & SGTA \\
\hline COX5B & CG11015 & PA & 296 & 8 & $\begin{array}{l}2 \text { mitochondrial electron transport, } \\
\text { cytochrome } \mathrm{c} \text { to oxygen }\end{array}$ & mitochondrion & Cox5B \\
\hline kcc & CG5594 & PA & 294 & 6 & 3 transport & $\begin{array}{l}\text { integral component of } \\
\text { membrane }\end{array}$ & SLC12A5 \\
\hline Prx3 & CG5826 & PA & 294 & 9 & 5 cell redox homeostasis & mitochondrion & PRDX2 \\
\hline emb & CG13387 & PA & 292 & 8 & 5 protein export from nucleus & nuclear pore & XPO1 \\
\hline CG9391 & CG9391 & PA & 291 & 5 & 3 dephosphorylation & cytoplasm & IMPA2 \\
\hline $\operatorname{Sec} 22$ & CG7359 & PA & 290 & 5 & 2 vesicle-mediated transport & transport vesicle & SEC22B \\
\hline sqh & CG3595 & PA & 283 & 6 & 3 ovarian follicle cell development & $\begin{array}{l}\text { unconventional myosin } \\
\text { complex }\end{array}$ & MYL12B \\
\hline LKRSDH & CG7144 & PA & 281 & 6 & 5 regulation of histone methylation & - & AASS \\
\hline Exo84 & CG6095 & PA & 279 & 4 & 3 meiotic spindle organization & exocyst & EXOC8 \\
\hline FK506-bp1 & CG6226 & PA & 278 & 6 & 2 protein folding & nucleus & PPID \\
\hline Prosbeta1 & CG8392 & PA & 278 & 8 & $\begin{array}{l}3 \text { cellular response to DNA damage } \\
\text { stimulus }\end{array}$ & proteasome core complex & PSMB6 \\
\hline poly & CG9829 & PA & 277 & 3 & $\begin{array}{l}2 \text { oocyte microtubule cytoskeleton } \\
\text { polarization }\end{array}$ & cellular_component & \\
\hline Arpc5 & CG9881 & PA & 270 & 8 & 5 cell morphogenesis & lamellipodium & ARPC5 \\
\hline CG1640 & CG1640 & PB & 269 & 6 & 5 biosynthetic process & mitochondrion & GPT2 \\
\hline Rab35 & CG9575 & PC & 268 & 8 & 2 mitotic cytokinesis & lipid particle & RAB8B \\
\hline Ppt1 & CG12108 & PA & 267 & 9 & 4 macromolecule depalmitoylation & Iysosome & PPT1 \\
\hline
\end{tabular}


Table 2. Top 100 unique hits found in mass spectrometry output from GFP::Spg11-C purification from Act-Spg11- C::GFP. Biological process and human ortholog (Human Ortho) data from Flybase (www.flybase.org). Some of the hits discussed in the text are in bold.

\begin{tabular}{|c|c|c|c|c|c|c|c|}
\hline Gene & Protein & CDS & Score & $\begin{array}{l}\text { Mat } \\
\text { che } \\
\text { s }\end{array}$ & \begin{tabular}{l|l} 
Seq & Biological Process \\
uen & \\
ces &
\end{tabular} & Cellular Component & $\begin{array}{l}\text { Human } \\
\text { Ortho }\end{array}$ \\
\hline MIc-c & CG3201 & PA & 8379 & 178 & 11 actin filament-based movement & myosin complex & MYL6B \\
\hline sqh & CG3595 & PA & 5723 & 117 & 8 ovarian follicle cell development & $\begin{array}{l}\text { unconventional myosin } \\
\text { complex }\end{array}$ & MYL12B \\
\hline Actn & CG4376 & PA & 4354 & 115 & 28 actin filament bundle assembly & focal adhesion & ACTN4 \\
\hline Gel & CG1106 & PA & 3844 & 103 & 23 phagocytosis & actin filament & AVIL \\
\hline CG13531 & CG13531 & PB & 3373 & 81 & 13 axon extension & axon & SPG11 \\
\hline Swip-1 & CG10641 & PA & 2215 & 43 & 9 mesoderm development & muscle tendon junction & EFHD1 \\
\hline $\mathrm{cpb}$ & CG17158 & PA & 1892 & 39 & 10 microtubule-based movement & dynactin complex & CAPZB \\
\hline cpa & CG10540 & PA & 1701 & 44 & 9 actin filament organization & dynactin complex & CAPZA1 \\
\hline Arp3 & CG7558 & PA & 1452 & 35 & 11 actin cytoskeleton organization & actin filament & ACTR3 \\
\hline didum & CG2146 & PA & 1215 & 28 & $\begin{array}{l}13 \text { anterior/posterior axis specification, } \\
\text { embryo }\end{array}$ & myosin complex & MYO5B \\
\hline Arpc2 & CG10954 & PA & 1171 & 43 & 6 lateral inhibition & Arp2/3 protein complex & ARPC2 \\
\hline didum & CG2146 & PB & 931 & 23 & $\begin{array}{l}11 \text { anterior/posterior axis specification, } \\
\text { embryo }\end{array}$ & myosin complex & MYO5B \\
\hline CG15099 & CG15099 & PA & 882 & 15 & 3 & & DOPEY2 \\
\hline Arp53D & CG5409 & PB & 829 & 40 & 2 cytoskeleton organization & actin filament & ACTBL2 \\
\hline Cisd2 & CG1458 & PA & 801 & 17 & 3 & $\begin{array}{l}\text { intracellular membrane- } \\
\text { bounded organelle }\end{array}$ & CISD2 \\
\hline msk & CG7935 & PA & 775 & 12 & 5 protein import into nucleus & cytoplasm & IPO7 \\
\hline Arpc1 & CG8978 & PB & 772 & 22 & 9 actin filament polymerization & Arp2/3 protein complex & ARPC1B \\
\hline Arpc3A & CG4560 & PC & 690 & 13 & $\begin{array}{l}4 \text { Arp } 2 / 3 \text { complex-mediated actin } \\
\text { nucleation }\end{array}$ & Arp2/3 protein complex & ARPC3 \\
\hline CG6707 & CG6707 & PA & 540 & 19 & $\begin{array}{l}4 \text { phosphatidylinositol } \\
\text { dephosphorylation }\end{array}$ & lysosomal membrane & TMEM55B \\
\hline Hmt-1 & CG4225 & PA & 534 & 8 & 2 heme transport & $\begin{array}{l}\text { ATP-binding cassette } \\
\text { (ABC) transporter complex }\end{array}$ & ABCB7 \\
\hline ck & CG7595 & PA & 507 & 11 & 6 sensory perception of sound & $\begin{array}{l}\text { unconventional myosin } \\
\text { complex }\end{array}$ & MYO7B \\
\hline CG32521 & CG32521 & PA & 446 & 7 & $2-$ & - & \\
\hline tmod & CG1539 & PA & 442 & 11 & 5 cytoskeleton organization & fusome & \\
\hline mon2 & CG8683 & PB & 391 & 10 & 6 pole plasm protein localization & endosome & MON2 \\
\hline elF4G & CG10811 & PA & 384 & 6 & 3 translational initiation & cytosol & EIF4G1 \\
\hline CG4042 & CG4042 & PA & 380 & 24 & $1-$ & - & ATP5SL \\
\hline Gie & CG7891 & PA & 380 & 6 & 2 sister chromatid segregation & lysosome & ARL8B \\
\hline CG8578 & CG8578 & PA & 348 & 6 & 4 adult somatic muscle development & - & LRRFIP1 \\
\hline CG32521 & CG32521 & PG & 338 & 4 & $1-$ & - & \\
\hline AlaRS & CG13391 & PB & 338 & 5 & 2 alanyl-tRNA aminoacylation & cytoplasm & AARS \\
\hline ValRS & CG4062 & PB & 331 & 5 & 3 valyl-tRNA aminoacylation & cytoplasm & VARS \\
\hline CG7806 & CG7806 & PA & 313 & 8 & 4 transmembrane transport & $\begin{array}{l}\text { integral component of } \\
\text { membrane }\end{array}$ & $\mathrm{ABCC} 4$ \\
\hline Cp1 & CG6692 & PA & 303 & 7 & 2 protein catabolic process & lysosome & CTSS \\
\hline Aldh-III & CG11140 & PE & 285 & 6 & 3 oxidation-reduction process & lipid particle & GK5 \\
\hline FASN1 & CG3523 & PA & 285 & 5 & 5 triglyceride biosynthetic process & lipid particle & FASN \\
\hline Arpc5 & CG9881 & PA & 278 & 7 & 1 cell morphogenesis & lamellipodium & ARPC5 \\
\hline CG4552 & CG4552 & PA & 276 & 4 & 2 border follicle cell migration & - & TBC1D23 \\
\hline jar & CG5695 & PB & 271 & 8 & 4 membrane organization & $\begin{array}{l}\text { unconventional myosin } \\
\text { complex }\end{array}$ & MYO6 \\
\hline Pp1-87B & CG5650 & PA & 262 & 4 & 2 protein dephosphorylation & $\begin{array}{l}\text { protein phosphatase type } \\
1 \text { complex }\end{array}$ & PPP1CC \\
\hline CG31729 & CG31729 & PA & 238 & 5 & 2 phospholipid translocation & $\begin{array}{l}\text { integral component of } \\
\text { membrane }\end{array}$ & ATP9B \\
\hline pav & CG1258 & PA & 228 & 5 & 4 neurogenesis & kinesin complex & KIF23 \\
\hline
\end{tabular}




\begin{tabular}{|c|c|c|c|c|c|c|c|}
\hline CG17272 & CG17272 & PA & 226 & 3 & $2-$ & - & \\
\hline$r$ & CG18572 & PA & 225 & 6 & $\begin{array}{l}2 \text { 'de novo' pyrimidine nucleobase } \\
\text { biosynthetic process }\end{array}$ & cytoplasm & CPS1 \\
\hline Tango7 & CG8309 & PA & 220 & 3 & 1 Golgi organization & Golgi apparatus & EIF3M \\
\hline RhoGDI & CG7823 & PA & 211 & 7 & $2-$ & cytoplasm & ARHGDIA \\
\hline Cand1 & CG5366 & PA & 207 & 2 & 2 regulation of protein stability & - & CAND1 \\
\hline PRL-1 & CG4993 & PA & 206 & 3 & 2 protein dephosphorylation & cytoplasm & PTP4A2 \\
\hline Rack1 & CG7111 & PA & 206 & 7 & 3 oviposition & cytoplasm & GNB2L1 \\
\hline Snx1 & CG2774 & PA & 205 & 5 & 1 intracellular protein transport & $\begin{array}{l}\text { retromer, tubulation } \\
\text { complex }\end{array}$ & SNX1 \\
\hline CG11334 & CG11334 & PA & 202 & 5 & 1 translation & $\begin{array}{l}\text { eukaryotic translation } \\
\text { initiation factor } 2 \mathrm{~B} \text { complex }\end{array}$ & MRI1 \\
\hline Rab39 & CG12156 & PA & 198 & 7 & 2 Rab protein signal transduction & Golgi apparatus & RAB39A \\
\hline Arp2 & CG9901 & PA & 194 & 6 & 3 cytoskeleton organization & actin filament & ACTR2 \\
\hline RabX4 & CG31118 & PA & 179 & 6 & 1 Rab protein signal transduction & synapse & RAB10 \\
\hline Arpc4 & CG5972 & PA & 177 & 6 & 4 cell projection assembly & Arp2/3 protein complex & ARPC4 \\
\hline Iva & CG6450 & PC & 177 & 4 & 2 cellularization & Golgi apparatus & CEP250 \\
\hline FK506-bp1 & CG6226 & PA & 176 & 7 & 4 protein folding & nucleus & PPID \\
\hline rhea & CG6831 & PB & 172 & 2 & $\begin{array}{l}2 \text { cytoskeletal anchoring at plasma } \\
\text { membrane }\end{array}$ & focal adhesion & TLN2 \\
\hline row & CG8092 & PA & 170 & 3 & $\begin{array}{l}1 \text { regulation of transcription, DNA- } \\
\text { templated }\end{array}$ & protein complex & \\
\hline Pgi & CG8251 & PA & 169 & 2 & 1 gluconeogenesis & lipid particle & GPI \\
\hline Osbp & CG6708 & PA & 167 & 2 & 2 sperm individualization & endoplasmic reticulum & OSBP2 \\
\hline uex & CG42595 & PE & 162 & 5 & 2 cellular ion homeostasis & cellular_component & CNNM2 \\
\hline Hex-A & CG3001 & PA & 159 & 2 & 1 carbohydrate phosphorylation & - & HK2 \\
\hline $\mathrm{msn}$ & CG16973 & PA & 158 & 9 & 2 photoreceptor cell morphogenesis & cell cortex & TNIK \\
\hline vimar & CG3572 & PB & 154 & 4 & 1 tricarboxylic acid cycle & plasma membrane & $\begin{array}{l}\text { RAP1GDS } \\
1\end{array}$ \\
\hline Rack1 & CG7111 & PB & 151 & 4 & 2 oviposition & cytoplasm & GNB2L1 \\
\hline Glt & CG9280 & PA & 150 & 1 & 1 synaptic target inhibition & basement membrane & \\
\hline Rpn13 & CG13349 & PA & 146 & 3 & 2 lateral inhibition & $\begin{array}{l}\text { proteasome regulatory } \\
\text { particle }\end{array}$ & ADRM1 \\
\hline CG9281 & CG9281 & PB & 144 & 4 & $1-$ & $\begin{array}{l}\text { ATP-binding cassette } \\
\text { (ABC) transporter complex }\end{array}$ & ABCF2 \\
\hline alien & CG9556 & PA & 141 & 1 & 1 protein stabilization & COP9 signalosome & \\
\hline Dhc64C & CG7507 & PA & 138 & 4 & 4 cellularization & cytoplasm & DYNC1H1 \\
\hline CG7878 & CG7878 & PA & 136 & 4 & $2-$ & - & DDX53 \\
\hline $\begin{array}{l}\text { Kap- } \\
\text { alpha3 }\end{array}$ & CG9423 & PA & 135 & 1 & 1 protein import into nucleus & nuclear pore & KPNA2 \\
\hline SerRS & CG17259 & PA & 135 & 2 & 1 seryl-tRNA aminoacylation & cytoplasm & SARS \\
\hline Rme-8 & CG8014 & PA & 133 & 4 & 3 endocytosis & $\begin{array}{l}\text { microtubule associated } \\
\text { complex }\end{array}$ & DNAJC13 \\
\hline Pp1-Y2 & CG40448 & PB & 131 & 2 & 1 protein dephosphorylation & nucleus & PPP1CC \\
\hline Gbeta13F & CG10545 & PB & 129 & 2 & 1 actin filament organization & $\begin{array}{l}\text { heterotrimeric G-protein } \\
\text { complex }\end{array}$ & GNB4 \\
\hline CG5482 & CG5482 & PA & 129 & 2 & 1 protein folding & endomembrane system & FKBP8 \\
\hline Imp & CG1691 & $\mathrm{PC}$ & 126 & 2 & 1 nervous system development & precatalytic spliceosome & IGF2BP3 \\
\hline Stam & CG6521 & PA & 125 & 3 & 1 JAK-STAT cascade & ESCRT-0 complex & STAM2 \\
\hline MetRS & CG15100 & PA & 125 & 1 & 1 methionyl-tRNA aminoacylation & $\begin{array}{l}\text { microtubule associated } \\
\text { complex }\end{array}$ & MARS \\
\hline CG12065 & CG12065 & PA & 124 & 2 & 1 lateral inhibition & - & \\
\hline SPARC & CG6378 & PA & 123 & 2 & 1 cell adhesion & basement membrane & SPARCL1 \\
\hline Gdi & CG4422 & PA & 119 & 2 & 2 neurotransmitter secretion & synaptic vesicle & GDI2 \\
\hline Mrp4 & CG14709 & PB & 118 & 1 & 1 drug transmembrane transport & $\begin{array}{l}\text { ATP-binding cassette } \\
(\mathrm{ABC}) \text { transporter complex }\end{array}$ & $\mathrm{ABCC} 4$ \\
\hline CG9044 & CG9044 & PB & 118 & 1 & 1 protein localization & cytoplasm & STK11IP \\
\hline $\mathrm{msn}$ & CG16973 & PB & 117 & 8 & 1 photoreceptor cell morphogenesis & cell cortex & TNIK \\
\hline Flo2 & CG32593 & PF & 117 & 2 & 2 cell adhesion & flotillin complex & FLOT2 \\
\hline
\end{tabular}


bioRxiv preprint doi: https://doi.org/10.1101/2020.03.08.982389; this version posted September 13,2020 . The copyright holder for this preprint (which was not certified by peer review) is the author/funder, who has granted bioRxiv a license to display the preprint in perpetuity. It is made available under aCC-BY-NC 4.0 International license.

\begin{tabular}{|c|c|c|c|c|c|c|c|}
\hline CG10425 & CG10425 & PA & 116 & 1 & $1-$ & - & KDSR \\
\hline raptor & CG4320 & PB & 114 & 3 & $\begin{array}{l}2 \text { positive regulation of protein } \\
\text { phosphorylation }\end{array}$ & TORC1 complex & RPTOR \\
\hline shot & CG18076 & PA & 114 & 1 & 1 muscle attachment & fusome & SMTN \\
\hline Flo2 & CG32593 & PC & 107 & 1 & 1 cell adhesion & flotillin complex & FLOT2 \\
\hline Сyp9c1 & CG3616 & PA & 107 & 1 & 1 oxidation-reduction process & membrane & CYP4F12 \\
\hline KIp61F & CG9191 & PA & 105 & 2 & 2 neurogenesis & cytoplasm & KIF11 \\
\hline PpD3 & CG8402 & PB & 103 & 3 & 1 protein dephosphorylation & nucleus & PPP5C \\
\hline blp & CG5268 & PA & 101 & 1 & $\begin{array}{l}1 \text { embryonic development via the } \\
\text { syncytial blastoderm }\end{array}$ & cellular_component & PAM16 \\
\hline CG8336 & CG8336 & PB & 99 & 6 & 1 protein folding & - & PPID \\
\hline CG3587 & CG3587 & PA & 98 & 2 & $1-$ & - & KTI12 \\
\hline CG30122 & CG30122 & PB & 98 & 1 & 1 mRNA splicing, via spliceosome & precatalytic spliceosome & \\
\hline Vps35 & CG5625 & PA & 98 & 1 & 1 vesicle-mediated transport & endosome & VPS35 \\
\hline
\end{tabular}


bioRxiv preprint doi: https://doi.org/10.1101/2020.03.08.982389; this version posted September $13,2020$. The copyright holder for this preprint (which was not certified by peer review) is the author/funder, who has granted bioRxiv a license to display the preprint in perpetuity. It is made available under aCC-BY-NC 4.0 International license.

\section{Table 3. Protein hits identified from GFP::Spg11-C purification from both Act5-} GFP::Spg11-C and PMT-GFP::Spg11-C. Proteins are ranked by highest score present in either of the two lines. Proteins mentioned in the text are highlighted. Human orthologue (Human Orth) data are from Flybase (www.flybase.org). Some of the hits discussed in the text are in bold.

\begin{tabular}{|c|c|c|c|c|c|c|c|c|c|c|c|}
\hline \# & Protein & Gene & \begin{tabular}{|l} 
Human \\
Orth
\end{tabular} & \# & Protein & Gene & \begin{tabular}{|l} 
Human \\
Orth
\end{tabular} & \# & Protein & Gene & Human Orth \\
\hline 1 & CG13531 & CG13531 & SPG11 & 51 & CG15811 & Rop & STXBP3 & 101 & CG1828 & dre4 & SUPT16H \\
\hline 2 & CG5409 & Arp53D & ACTBL2 & 52 & CG13849 & Nop56 & NOP58 & 102 & CG7207 & cert & COL4A3BP \\
\hline 3 & CG2241 & Rpt6R & PSMC2 & 53 & CG10990 & $P d c d 4$ & PDCD4 & 103 & CG6020 & $N D-39$ & ENS \\
\hline 4 & CG7878 & CG7878 & DDX53 & 54 & CG5650 & Pp1-87B & PPP1CC & 104 & CG5336 & Ced-12 & ELMO3 \\
\hline 5 & CG1458 & Cisd2 & CISD2 & 55 & CG3523 & FASN1 & FASN & 105 & CG1484 & flil & FLII \\
\hline 6 & CG11765 & Prx2540-2 & PRDX6 & 56 & CG5504 & I(2)tid & DNAJA3 & 106 & CG4993 & $P R L-1$ & PTP4A2 \\
\hline 7 & CG12156 & Rab39 & RAB39A & 57 & CG3991 & Tpp/l & TPP2 & 107 & CG4042 & CG4042 & ATP5SL \\
\hline 8 & CG31118 & RabX4 & RAB10 & 58 & CG12400 & $N D-B 14.5 B$ & & 108 & CG43398 & scrib & SCRIB \\
\hline 9 & CG5729 & $D g p-1$ & GTPBP1 & 59 & CG11804 & ced-6 & GULP1 & 109 & CG2774 & Snx1 & SNX1 \\
\hline 10 & CG15100 & MetRS & MARS & 60 & CG3201 & MIC-C & MYL6B & 110 & CG6963 & gish & CSNK1G3 \\
\hline 11 & CG11140 & Aldh-III & GK5 & 61 & CG10539 & $S 6 k$ & RPS6KA3 & 111 & CG12202 & NAA15-16 & NAA15 \\
\hline 12 & CG15871 & $m R p L 38$ & MRPL38 & 62 & CG5625 & Vps35 & VPS35 & 112 & CG5482 & CG5482 & FKBP8 \\
\hline 13 & CG10811 & elF4G & EIF4G1 & 63 & CG4931 & Sra-1 & CYFIP1 & 113 & CG6708 & Osbp & OSBP2 \\
\hline 14 & CG18572 & $r$ & CPS1 & 64 & CG1987 & Rbp1-like & SRSF3 & 114 & CG17158 & $c p b$ & CAPZB \\
\hline 15 & CG17514 & CG17514 & GCN1 & 65 & CG18076 & shot & SMTN & 115 & CG9186 & CG9186 & LDAH \\
\hline 16 & CG8309 & Tango7 & EIF3M & 66 & CG32056 & scramb1 & PLSCR1 & 116 & CG6450 & Iva & CEP250 \\
\hline 17 & CG1100 & Rpn5 & PSMD12 & 67 & CG30122 & CG30122 & & 117 & CG8578 & CG8578 & LRRFIP1 \\
\hline 18 & CG10206 & nop5 & NOP58 & 68 & CG7558 & Arp3 & ACTR3 & 118 & CG7421 & Nopp140 & NOLC1 \\
\hline 19 & CG6692 & Cp1 & CTSS & 69 & CG7324 & CG7324 & TBC1D9 & 119 & CG8207 & CG8207 & GMPPA \\
\hline 20 & CG14709 & Mrp4 & ABCC4 & 70 & CG4062 & ValRS & VARS & 120 & CG30159 & CG30159 & \\
\hline 21 & CG7507 & Dhc64C & DYNC1H1 & 71 & CG7111 & Rack1 & GNB2L1 & 121 & CG7985 & CG7985 & HEXDC \\
\hline 22 & CG6831 & rhea & TLN2 & 72 & CG10506 & GInRS & QARS & 122 & CG43947 & PSGEF & \\
\hline 23 & CG7935 & msk & IPO7 & 73 & CG8261 & Ggamma1 & GNG10 & 123 & CG7035 & Cbp80 & NCBP1 \\
\hline 24 & CG43443 & hts & & 74 & CG3585 & $R b c n-3 A$ & DMXL1 & 124 & CG5268 & blp & PAM16 \\
\hline 25 & CG5366 & Cand1 & CAND1 & 75 & CG32138 & $F r l$ & DAAM2 & 125 & CG8989 & His3.3B & HIST1H3B \\
\hline 26 & CG5594 & $k c c$ & SLC12A5 & 76 & CG4422 & Gdi & GDI2 & 126 & CG7538 & Mcm2 & MCM2 \\
\hline 27 & CG3431 & Uch-L5 & UCHL5 & 77 & CG3299 & Vinc & $\mathrm{VCL}$ & 127 & CG6707 & CG6707 & TMEM55B \\
\hline 28 & CG17259 & SerRS & SARS & 78 & CG9423 & Kap-alpha3 & KPNA2 & 128 & CG4320 & raptor & RPTOR \\
\hline 29 & CG8402 & $P p D 3$ & PPP5C & 79 & CG10545 & Gbeta13F & GNB4 & & & & \\
\hline 30 & CG3616 & Cyp9c1 & CYP4F12 & 80 & CG10913 & Spn55B & SERPINB2 & & & & \\
\hline 31 & CG5094 & Sgt & SGTA & 81 & CG4265 & Uch & UCHL3 & & & & \\
\hline 32 & CG11015 & COX5B & Cox5B & 82 & CG3001 & Hex-A & HK2 & & & & \\
\hline 33 & CG3595 & sqh & MYL12B & 83 & CG8014 & Rme-8 & DNAJC13 & & & & \\
\hline 34 & CG6226 & FK506-bp1 & PPID & 84 & CG8683 & mon2 & MON2 & & & & \\
\hline 35 & CG9881 & Arpc5 & ARPC5 & 85 & CG17950 & $H m g D$ & SSRP1 & & & & \\
\hline 36 & CG12108 & Ppt1 & PPT1 & 86 & CG8284 & Ubc4 & UBE2K & & & & \\
\hline 37 & CG7619 & Rpn10 & PIP5K1C & 87 & CG12918 & sel & CNPY1 & & & & \\
\hline 38 & CG9281 & CG9281 & ABCF2 & 88 & CG5252 & Ranbp9 & IPO9 & & & & \\
\hline 39 & CG10425 & CG10425 & KDSR & 89 & CG8487 & garz & GBF1 & & & & \\
\hline 40 & CG13349 & Rpn13 & ADRM1 & 90 & CG12132 & c11.1 & MROH7 & & & & \\
\hline 41 & CG3226 & CG3226 & CACYBP & 91 & CG12065 & CG12065 & & & & & \\
\hline 42 & CG34373 & Sarm & SARM1 & 92 & CG4225 & $H m t-1$ & ABCB7 & & & & \\
\hline 43 & CG16973 & $m s n$ & TNIK & 93 & CG10161 & elF-3p66 & EIF3D & & & & \\
\hline 44 & CG8251 & $P g i$ & GPI & 94 & CG14616 & I(1)G0196 & PPIP5K1 & & & & \\
\hline 45 & CG9242 & bur & GMPS & 95 & CG42595 & uex & CNNM2 & & & & \\
\hline 46 & CG13391 & AlaRS & AARS & 96 & CG3572 & vimar & RAP1GDS1 & & & & \\
\hline 47 & CG1691 & Imp & IGF2BP3 & 97 & CG11334 & CG11334 & MRI1 & & & & \\
\hline 48 & CG6783 & fabp & FABP2 & 98 & CG4560 & Arpc3A & ARPC3 & & & & \\
\hline 49 & CG3593 & $r-I$ & UMPS & 99 & CG7806 & CG7806 & ABCC4 & & & & \\
\hline 50 & CG7891 & Gie & ARL8B & 100 & CG8715 & lig & UBAP2 & & & & \\
\hline
\end{tabular}


Table 4. Enrichment analysis for Spg11 C-terminal interactors identified in both constitutive and inducible interaction screens.

Enrichment analysis is shown for human orthologs. GO terms with large gene sets (>2000) and smaller sets with less specific terms are omitted. Full lists are in Supplementary Information.

\begin{tabular}{|c|c|c|c|c|c|c|}
\hline GO-term & Molecular Fun & tion & & & set & Disce \\
\hline GO:0008144 & drug binding & & & & 32 of 1710 & $2.97 \mathrm{E}$ \\
\hline GO:0005524 & ATP binding & & & & 29 of 1462 & $2.97 \mathrm{E}$ \\
\hline GO:0004812 & aminoacyl-tRN/ & ligase a & ctivity & & 5 of 43 & .00 \\
\hline GO:0003723 & RNA binding & & & & 17 of 850 & \\
\hline GO:0140296 & general transcri & tion init & ation fact & or binding & 4 of 39 & \\
\hline GO:0045182 & translation regu & ator acti & & & 6 of 124 & 0.0 \\
\hline GO:0003779 & actin binding & & & & 10 of 413 & \\
\hline GO-term & Biological Pro & ess & & & & \\
\hline GO:0006897 & vesicle-mediate & transp & & & 30 of 1699 & 0.00 \\
\hline GO:0016192 & regulated exocy & osis & & & 17 of 691 & \\
\hline GO:0051234 & neutrophil degre & nulation & & & 14 of 485 & 0.0 \\
\hline GO:0043604 & phagocytosis & & & & 9 of 185 & 0.0 \\
\hline GO:0006810 & endocytosis & & & & 14 of 510 & 0.0 \\
\hline GO:0045055 & translation & & & & 12 of 362 & 0.0 \\
\hline GO:0043312 & cell activation in & volved ir & immune & response & 15 of 620 & 0.0 \\
\hline GO:1901566 & secretion & & & & 20 of 1070 & 0.00 \\
\hline GO:0006909 & membrane orga & nization & & & 16 of 729 & \\
\hline KEGG Pathway & Description & & & & & \\
\hline dme00970 & Aminoacyl-tRN, & biosynt & nesis & & 5 of 42 & 0.0 \\
\hline dme04144 & Endocytosis & & & & 6 of 119 & 0.0 \\
\hline dme03050 & Proteasome & & & & 4 of 51 & 0.0 \\
\hline dme02010 & $A B C$ transporte & & & & 3 of 22 & \\
\hline Table 5. Amin & tRNA s] & & & & & \\
\hline & & T-GFP: & Spg11-C & & & \\
\hline $\begin{array}{l}\text { Drosophila } \\
\text { Protein }\end{array}$ & $\begin{array}{l}\text { Human } \\
\text { Ortholog }\end{array}$ & CDS & Score & Matches & Sequences & \\
\hline MetRS & MARS & $\mathrm{PA}$ & 1147 & & 26 & 14 \\
\hline SerRS & SARS & PA & 341 & & 6 & 4 \\
\hline AlaRS & AARS & PB & 338 & & 5 & 2 \\
\hline ValRS & VARS & PB & 331 & & 5 & 3 \\
\hline GInRS & QARS & PA & 125 & & 4 & 3 \\
\hline
\end{tabular}


Table 6. Members of the Sec1/Munc18 (SM) gene family in Drosophila

\begin{tabular}{l|ll} 
Gene Symbol & Gene Name & Also known as \\
\hline car & carnation & Vps33, Vps33a, I(1)G0447 \\
Rop & Ras opposite & I(3)64Ah, cs1, Sec1, Munc18 \\
SIh & SLY-1 homologous & Sly1, d-sly \\
Vps33B & Vacuolar protein sorting 33B & \\
Vps45 & Vacuolar protein sorting 45 & MEME(3R)-C
\end{tabular}

Table 7. Rop, Vps45, Slh and Spg15 mass spectrometry score results

\begin{tabular}{|c|c|c|c|c|c|}
\hline \multicolumn{6}{|c|}{ PMT-GFP::Spg11-C } \\
\hline Gene Symbol & Protein & CDS & Score & Matches & Sequences \\
\hline Rop & CG15811 & PA & 180 & & \\
\hline Vps45 & CG8228 & PA & 122 & & \\
\hline $\operatorname{Slh}$ & CG3539 & $\mathrm{PC}$ & 90 & & \\
\hline
\end{tabular}

